\title{
Compositional variation of clinopyroxenes of basaltic, essexitic and tephriphonolitic rocks from the Doupovské hory Volcanic Complex, NW Bohemia
}

Variace chemického složení klinopyroxenů v bazaltických, essexitových a tefrifonolitových horninách vulkanického komplexu Doupovských hor, severozápadní Čechy

\author{
(12 figs, 4 tabs) \\ VLADISLAV RAPPRICH ${ }^{1,2}$ \\ ${ }^{1}$ Czech Geological Survey, Klárov 3, 11821 Prague, Czech Republic; rapprich@cgu.cz \\ ${ }^{2}$ Faculty of Science, Charles Univ., Inst. Petrol. and Struct. Geol., Albertov 6, 12843 Prague, Czech Republic
}

Variation of chemical composition of clinopyroxenes in basaltic volcanic rocks, including lavas and shallow intrusions of the Doupovské hory Volcanic Complex, was studied. High Ca (mostly over $90 \%$ of M2 site) and Mg contents of analyzed clinopyroxenes qualify them as diopsides. With respect to $\mathrm{Al}$ and Ti admixtures, full name of titanian aluminian diopside should be used in most cases. The name augite, traditionally used in older literature without support by analytical data, is no more applicable. During crystallization of basaltic rocks, the composition of clinopyroxenes changed to Fe-rich diopside in phenocryst rims and matrix microcrysts. The contents of $\mathrm{Al}$, Ti and $\mathrm{Fe}$ increased from cores to rims, whereas $\mathrm{Si}$ and $\mathrm{Mg}$ decreased. The same compositional shifts were observed in clinopyroxenes of essexitic rock. Record of compositional changes is documented in zoned clinopyroxene phenocrysts from tephriphonolite. Cores of these phenocrysts show composition similar to clinopyroxenes in basaltic rocks, whereas their rims are of sodian aluminian diopsidic composition differing significantly in higher $\mathrm{Fe} / \mathrm{Mg}$ and $\mathrm{Na} / \mathrm{Ca}$ ratios and a low Ti content.

Key words: Clinopyroxene; diopside; mineral chemistry; Doupovské hory Mts.; basalts; essexite; tephriphonolite

\section{Introduction}

Pyroxenes are the most abundant rock-forming minerals of basaltic rocks. Thanks to the long period during which pyroxenes crystallize - from first stage of crystallization in cores of large phenocrysts (together with olivine) to the late stage of microcrysts crystallization in matrix pyroxenes contain the most complete record of the crystallization history of basaltic magma. Pyroxenes, as important magmatic rock-forming minerals, are intensively studied worldwide (for review see Prewitt et al. 1982; Deer et al. 1997 and references therein). In contrast to this, the chemical composition of pyroxenes in Cenozoic volcanic rocks of the Bohemian Massif have been little studied (Ulrych 1983, 1986, 1998, Ulrych et al. 1990, 1991, 1998), and data on pyroxenes of volcanic rocks of the Doupovské hory volcanic complex (DHVC) are completely lacking. Apart from the studies mentioned above, compositional data for clinopyroxenes from the DHVC could be compared with mineralogical data available from comparable alkaline suites around the world. Pioneering systematic study of clinopyroxenes in alkali basaltoids of the Hocheifel area was done by Huckenholz $(1966,1973)$. In 70's, the general observations on clinopyroxenes in alkali basaltic rocks were summarized by Wass (1973, 1979). Clinopyroxenes from other Central European alkaline volcanic suites (Hungary) were studied by Dobosi (1987, 1989) and Dobosi et al. (2003). Clinopyroxene phenocrysts in relationships to evolution of basaltic system were studied by Liotard et al. (1988) in the French Massif Central. Crystalization trends of clinopyroxenes in alkaline rocks were studied on ocean islands of Atlan- tic (e.g. Tenerife: Scott 1976) and Pacific Oceans (e.g. Tahiti: Tracy - Robinson 1977) as well. Clinopyroxenes of composition similar to those from the DHVC were described from volcanic rocks, with geochemical characteristics similar to the DHVC, from Uganda (Simonetti et al. 1996). Clinopyroxenes in silicic alkaline rocks were studied by DePieri - Molin (1980) on the samples from the Euganean Hills (N Italy). The miscibility of Ca-Ti-Tschermak's molecule with diopside was studied by Gupta et al. (1973).

Geological, petrological and mineralogical studies in the DHVC (Fig. 1.) are scarce if compared to the situation in the České středohoří Mts. (e.g. Cajz et al. 1999; Ulrych et al. 2001). The presence of military training area in the Doupovské hory Mts. is only one of several reasons for this situation. A first more complex dataset of microprobe analyses of some rock-forming minerals was acquired by Rapprich (2003a) from northern parts of the DHVC.

Clinopyroxenes in Cenozoic volcanic rocks of the Bohemian Massif are traditionally classified as augites or aegirine-augites (e.g. Kopecký 1987-1988, a. o.). In Bohemia, the term "augite" was introduced in early $19^{\text {th }}$ century by Ponfikl (1822) for famous idiomorphic phenocrysts from Paškapole in České středohoří Volcanic Complex. For a long time, the distinction between augite and diopside was based solely on the slight difference in their optical parameters. Clinopyroxenes in DHVC were optically studied in the first half of $20^{\text {th }}$ century by Zartner (1938). The term "augite" became commonly used in České středohoří and Doupovské hory volcanic complexes and most authors used this name without test- 
ing its validity chemically, even though the classification of pyroxenes evolved meanwhile. In this respect are exceptional studies of Ulrych (1983, 1986), who proved diopsidic or salitic (currently merged to diopside) composition of clinopyroxenes from the České středohoří already in 80 's.

\section{Geological setting}

The Doupovské hory Mts. represent one of two major volcanic complexes of the Ohře/Eger Graben, the easternmost graben of the European Cenozoic Rift System (e.g. Christensen et al. 2001; Dèzes et al. 2004), see Fig. 1. Early studies (Zartner 1938; Kopecký 1987-1988) proposed prevailing explosive activity with minor lava effusions. Hypothesis of Kopecký (1987-1988), explaining the origin of this mountains, dealt with a single huge stratovolcano. Currently, geology of the Doupovské hory Mts. seems to be more complex, according to new studies (Hradecký 1997; Hradecký et al. 2000, 2005). Sequence of basaltic lavas with subordinate layers of Strombolian and Hawaiian pyroclastics (total thickness reaching $500 \mathrm{~m}$ ) overlay pyroclastic and epiclastic deposits of Upper-most Eocene and Lower Oligocene Strombolian up to Plinian explosive activity (Hradecký 1997;
Mikuláš et al. 2003). The younger, effusive activity is probably of Upper Oligocene to the Lowermost Miocene age. Lavas and pyroclastics were not produced from one central crater but from numerous conduits, often arranged along NE-SW trending tectonic zones (parallel to the Eger Graben). Layers of clastic deposits between individual bodies of compact lava were newly interpreted as autoclastic facies of lava flows (Hradecký 1997; Rapprich 2003b).

Subvolcanic rocks are exposed only scarcely as the entire complex is only moderately affected by erosion. The occurrence of subvolcanic essexite intrusion at the abandoned town of Doupov (Duppau) is known for a long time (Wiesbaur 1901).

Basaltic lavas are of relatively uniform composition. Analcimites, nephelinites, tephrites and basanites are the most common rock types accompanied by picrobasalts and alkali basalts (Shrbený 1982; Rapprich 2003b). Differentiated rocks are rare. Affinity of the Andělská hora and Šemnická skála phonolites, situated nearby the volcanic complex, to the DHVC is not clear. A tephriphonolitic dike has been newly discovered in the central part of the DHVC during geological mapping (Hradecký et al. 2005).

General geochemical characteristic of the DHVC products were outlined by Shrbený (1982) using major ele-

19

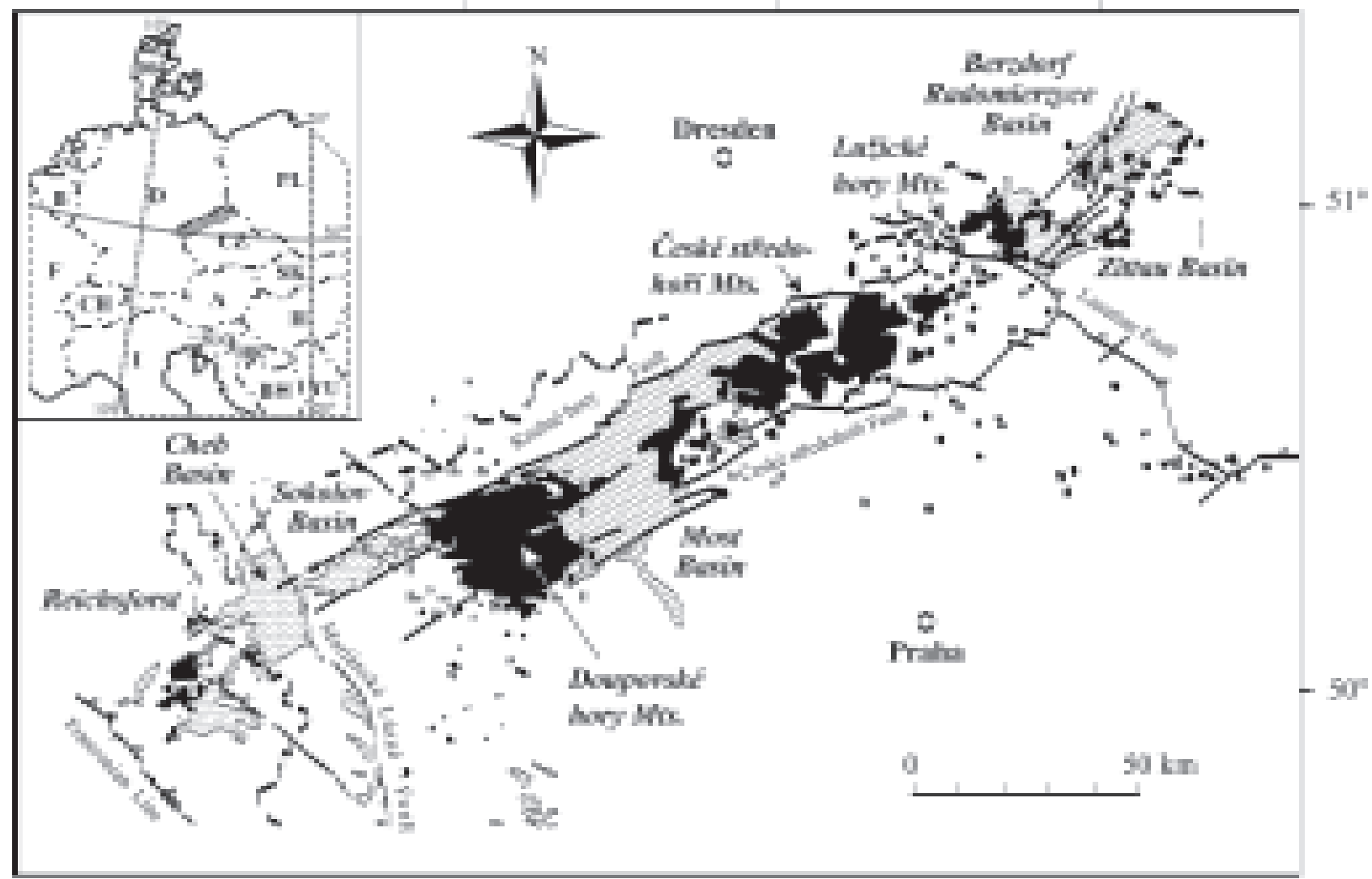

Fig. 1 Location of the Doupovské hory volcanic complex in the sketch map of the Ohře/Eger Graben (adapted after Christensen et al. 2001). Location of Fig. 2 is marked by dashed polygon. 


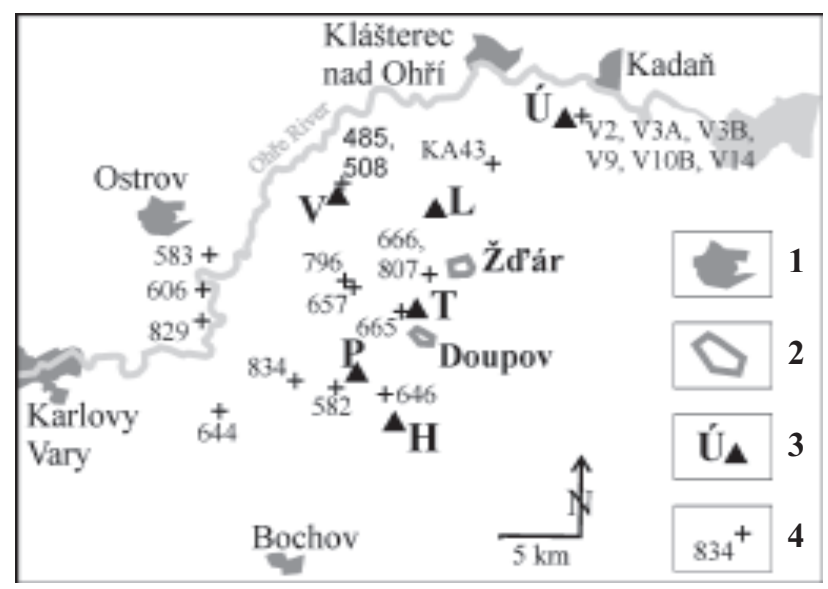

Fig. 2 Location of samples. 1 - major towns; 2 - abandoned towns (military training area); 3 - dominant hills: H - Hradiště hill, L - Lesná hill, P - Pustý zámek hill, Ú - Úhošt’ hill, V - Velká Jehličná hill; 4 - sampling sites. The letters "DH" were omitted from the numbers of samples in the sketch.

Table 1 Coordinates of analyzed samples.

\begin{tabular}{|c|c|c|}
\hline Sample & North & East \\
\hline DH485 & $50^{\circ} 19^{‘} 12.7^{،} ،$ & $13^{\circ} 04^{\prime} 48.8^{\prime ،}$ \\
\hline DH508 & $50^{\circ} 19^{\prime} 46.6^{\prime \prime}$ & $13^{\circ} 05^{\prime} 15.3^{\prime}$ \\
\hline DH582 & $50^{\circ} 13^{‘} 59.2^{،}$ & $13^{\circ} 05^{`} 05.7^{\prime}$ \\
\hline DH583 & $50^{\circ} 17^{‘} 26.2^{، \triangleleft}$ & $12^{\circ} 59^{\prime} 26.2^{\prime c}$ \\
\hline DH606 & $50^{\circ} 16^{‘} 36.8^{،}$ & $12^{\circ} 59^{\prime} 28.2^{\circ}$ \\
\hline DH644 & $50^{\circ} 13^{\prime} 04.5^{\prime ،}$ & $13^{\circ} 00^{‘} 12.0^{\circ}$ \\
\hline DH646 & $50^{\circ} 13^{‘} 43.7^{،}$ & $13^{\circ} 07^{\prime} 12.2^{\prime c}$ \\
\hline DH657 & $50^{\circ} 16^{\circ} 44.5^{\prime ،}$ & $13^{\circ} 05^{`} 30.7^{\prime}$ \\
\hline DH665 & $50^{\circ} 16^{\circ} 14.4^{، ،}$ & $13^{\circ} 07^{\circ} 43.7^{\circ}$ \\
\hline DH796 & $50^{\circ} 16^{\circ} 54.0^{،}$ & $13^{\circ} 05^{\circ} 05.6^{\circ}$ \\
\hline DH807 & $50^{\circ} 17^{\prime} 03.7^{\prime}$ & $13^{\circ} 08^{\prime} 53.6^{\prime}$ \\
\hline DH829 & $50^{\circ} 15^{‘} 36.9^{،}$ & $12^{\circ} 59^{\prime} 10.4^{\prime c}$ \\
\hline DH834 & $50^{\circ} 14^{\prime} 04.0^{\prime \prime}$ & $13^{\circ} 03^{\prime} 21.6^{\prime \prime}$ \\
\hline KA43 & $50^{\circ} 20^{\prime} 29.6^{\prime \prime}$ & $13^{\circ} 12^{\prime} 15.6^{\prime}$ \\
\hline $\mathbf{V 2}$ & $50^{\circ} 21^{\prime} 40.9^{\prime \prime}$ & $13^{\circ} 15^{\prime} 06.2^{\prime c}$ \\
\hline V3A & $50^{\circ} 21^{\prime} 40.9^{،}$ & $13^{\circ} 15^{\circ} 06.2^{\circ}$ \\
\hline V3B & $50^{\circ} 21^{\prime} 40.9^{\prime \prime}$ & $13^{\circ} 15^{\prime} 06.2^{\prime \prime}$ \\
\hline V9 & $50^{\circ} 21^{\prime} 33.3^{\prime \prime}$ & $13^{\circ} 14^{`} 09.4^{\prime \prime}$ \\
\hline V10B & $50^{\circ} 21^{\prime} 33.3^{\prime \prime}$ & $13^{\circ} 14^{\prime} 09.4^{\prime \prime}$ \\
\hline V14 & $50^{\circ} 21^{\prime} 33.3^{\prime \prime}$ & $13^{\circ} 14^{\circ} 09.4^{\circ}$ \\
\hline
\end{tabular}

ments. The projection of these data grouped with new analyses obtained within the framework of geological mapping (Hradecký et al. 2002, 2005) into the TAS diagram (Le Bas et al. 1986) show predominance of basaltic rocks clustered around the borders between foidite, tephrite/basanite, picrobasalt and (alkali) basalt fields.

\section{Petrological characteristics}

Analyzed clinopyroxenes were sampled from four principal rock types: basaltoids, picrobasalts (+ olivine-rich alkali basats), essexite and tephriphonolite. These rock types represent volcanic rocks forming the DHVC.

Basaltoids are the most abundant rocks present in the DHVC, mostly as lava flows or lava sheets. These rocks are relatively uniform in composition and consist of clinopyroxene, Fe-Ti oxides, nepheline/analcite and/or plagioclase and \pm olivine.
Picrobasalts are macroscopically well distinguishable among lavas of DHVC. This rock-type consists of abundant large phenocrysts of olivine and clinopyroxene (aprox. 50\% of the rock by volume), enclosed in finegrained matrix (clinopyroxene, Fe-Ti oxides, minor analcite). The picrobasaltic lavas are characterized by high $\mathrm{MgO}$ and low alkali contents. $\mathrm{Cr}$ and $\mathrm{Ni}$ contents are higher then in other basaltoids, but these values continuously decrease via olivinic basaltoids to olivine-free basaltoids and do not distinguishably separate picrobasalts from other rock types (foidites, tephrites, basanites and alkali basalts), common in DHVC.

Subvolcanic rocks occur scarcely in the DHVC and represent intrusive equivalents of superficial basaltoids. The sample KA43 represents essexitic rocks of the DHVC. Essexites in DHVC represent moderately evolved basaltic magma (equivalent to tephrites - Adamová in Hradecký et al. 2005). Essexite KA43 consists of large (up to $2.5 \mathrm{~cm}$ ) clinopyroxene phenocrysts forming approximately $60 \mathrm{vol} . \%$ and phenocrysts of nepheline. The matrix consists of plagioclase, Fe-Ti oxides and minor fine-grained clinopyroxene.

The silicic alkaline rocks are very rare in the DHVC. The studied tephriphonolite consists of abundant sanidine and nepheline, with not very common phenocrysts of clinopyroxene and amphibole. Both mafic minerals make together aggregates. Rims of amphiboles are often decomposed to a mixture of clinopyroxene, Fe-Ti oxides

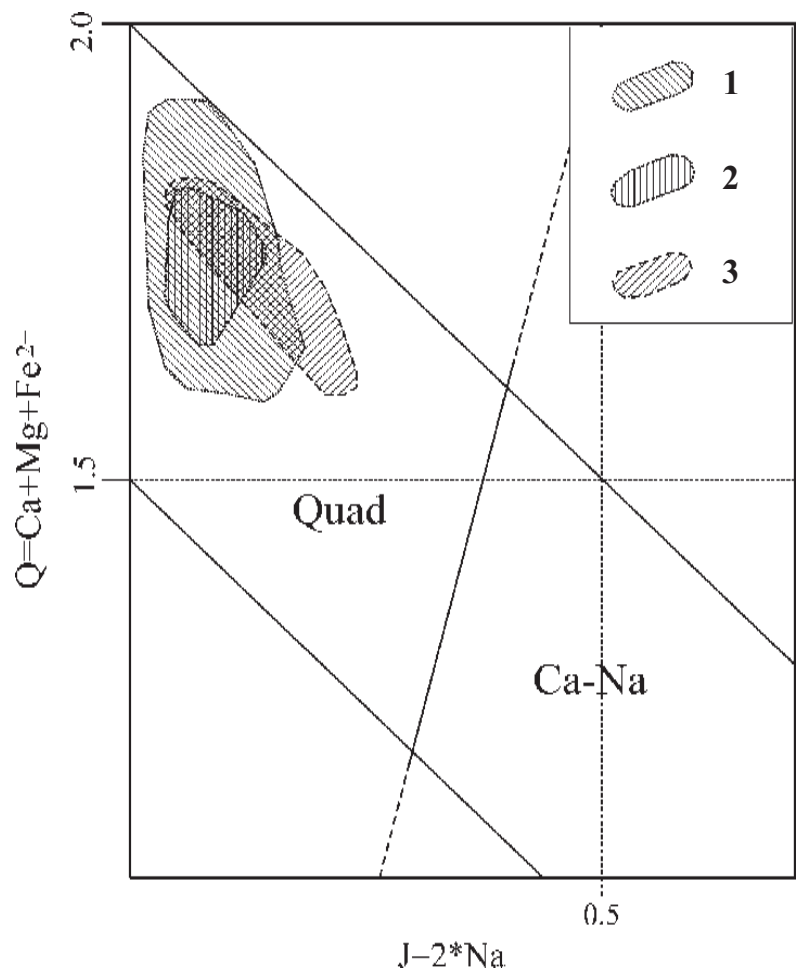

Fig. 3 Q-J classification diagram (Morimoto 1988). 1 - field of compositional range of clinopyroxenes from basaltic and picrobasaltic rocks $(\mathrm{n}=159) ; 2$ - field of compositional range of clinopyroxenes from essexite $(\mathrm{n}=15) ; 3$ - field of compositional range of clinopyroxenes from tephriphonolite $(n=8)$. 
and minor phlogopite. Sometimes amphibole is overgrown by clinopyroxene (Fig. 10).

\section{Sampling and analytical methods}

Rock samples for the study were collected mostly from basaltic lavas of the upper, predominantly effusive stage, essexite from north-eastern part of the DHVC (KA43 -

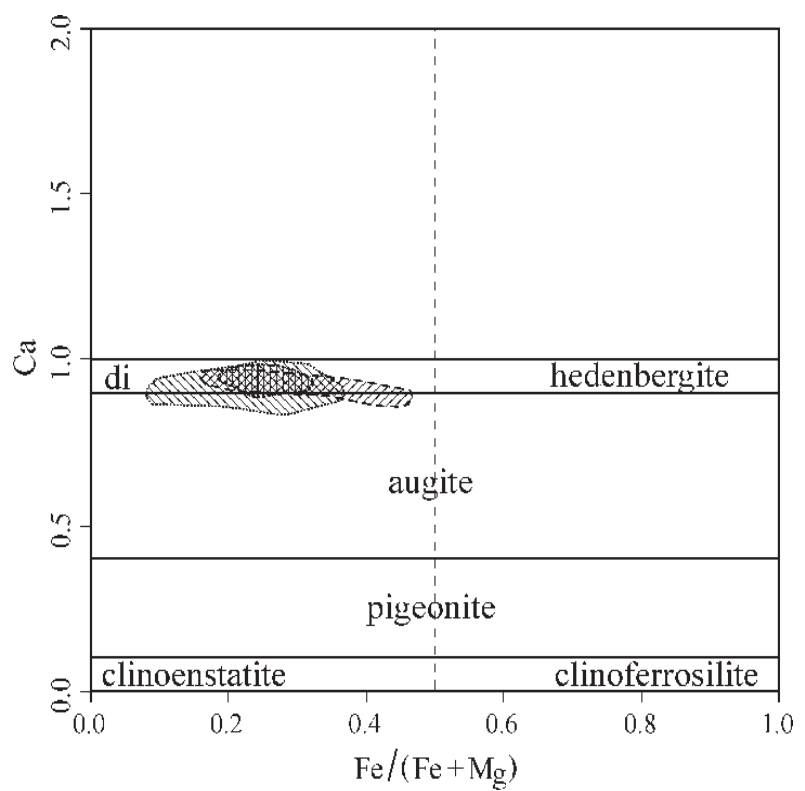

Fig. $4 \mathrm{Fe} /(\mathrm{Fe}+\mathrm{Mg}) / \mathrm{Ca}$ diagram (alternative to Wo-En-Fs quadrilateral). $\mathrm{X}$ axis shows $\mathrm{Fe} /(\mathrm{Fe}+\mathrm{Mg})$ molar ratio, where $\mathrm{Fe}=\mathrm{Fe}^{2+}+\mathrm{Fe}^{3+}+\mathrm{Mn}$, and is equivalent to Fs/(En+Fs) value (sensu Morimoto 1988). On the $\mathrm{Y}$ axis $\mathrm{Ca}$ (in $a p f u$ ) is plotted. Wo corresponds to $\mathrm{Ca}=2.0$. 0-2.0 range of $y$-axis $(\mathrm{Ca})$ was plotted for comparability with Wo-En-Fs diagram. Symbols of compositional fields of individual rock types correspond to previous figures. in Hradecký et al., 2000) and tephriphonolitic dike in the central part of the DHVC (DH796 in Hradecký et al. 2005). Sampling sites are shown in Fig. 2. and their coordinates are listed in Table 1.

The present work has been based on the dataset of 183 analysed clinopyroxenes from the DHVC, consisting of two subsets presented previously in manuscript reports and complemented by newly analyzed samples. Microprobe analytical data from rock-samples V2, V3A, V3B, V9, V10B, V14, DH485 and DH508 come from diploma thesis (Rapprich 2003a). Data from rock-samples DH582, DH583, DH606, DH644, DH646, DH657 and DH665 (the samples correspond to documentation points of the same numbers) were presented in explanatory notes to geological map 1:25 000, sheet 11-223 Kyselka (Hradecký et al. 2005). Clinopyroxenes from samples DH796, DH807, DH829, DH834 (documentation points in Hradecký et al. 2005) and KA43 (documentation point in Hradecký et al. 2000) were newly analyzed. The combined set of pyroxene analyses (Tables 2, 3, 4 and http://www.geologickaspolecnost.cz/jcgs/content/ JCGS2005_3-4_rapprich/) make statistically significant database.

All analyses were done in micro-analytical laboratory (LAREM) of the Czech Geological Survey, Prague. The first of the analytical subsets was analyzed by A. Gabašová in 2002, using scanning electron microprobe CamScan S4 at operation current 2.5-3 nA, voltage of $15 \mathrm{kV}$ and counting time of $100 \mathrm{~s}$. The second subset was acquired by K. Malý, P. Týcová and J. Haloda using CamScan 3400 analyzer. Analytical conditions were the same. Energy Dispersion System (EDS - Link ISIS 300) with Helios software was applied to acquire quantitative analyses. Accepted were analyses with $98.5<$ total $<101.0$.
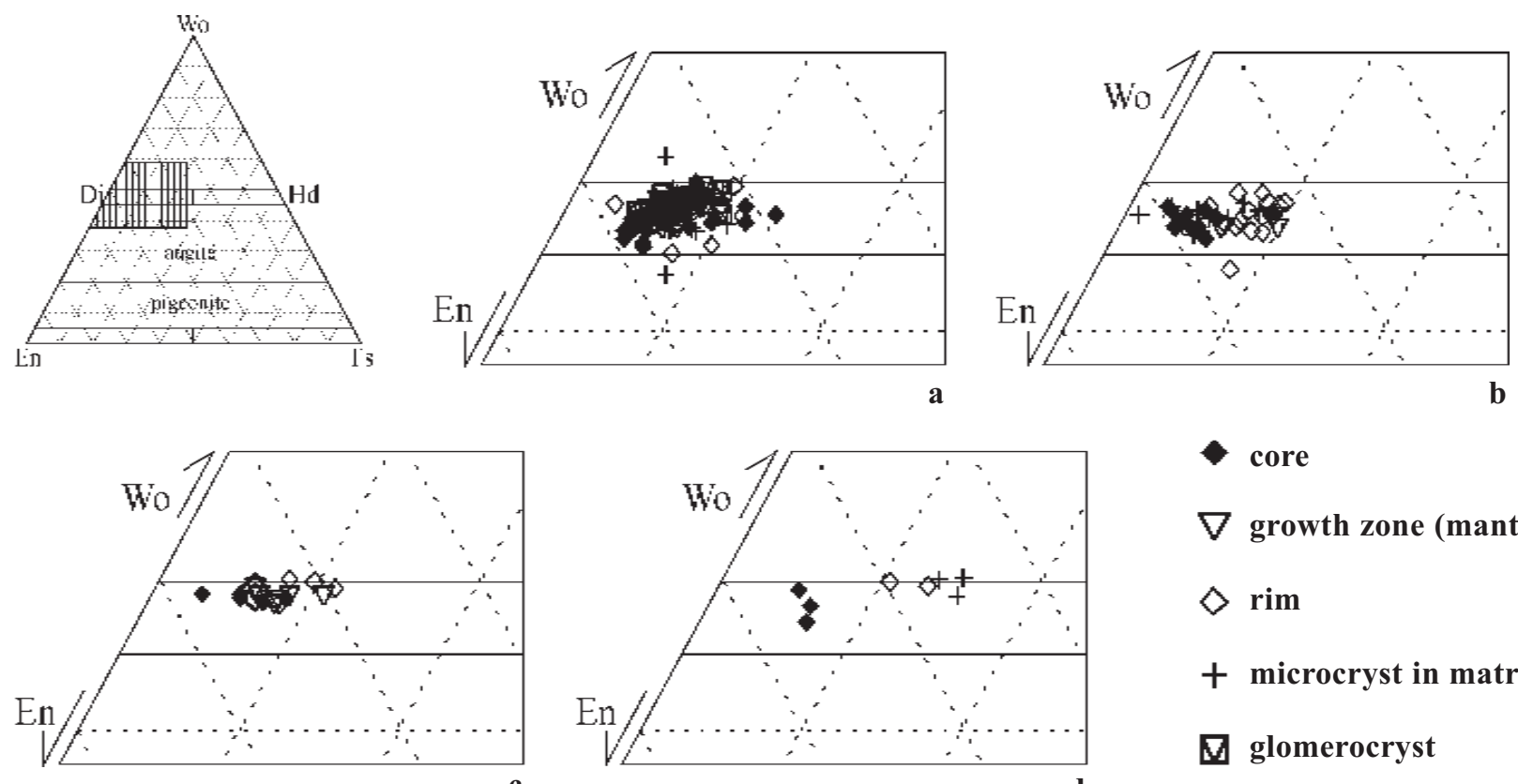

$\checkmark$ core

$\nabla$ growth zone (mantle)

rim

+ microcryst in matrix

glomerocryst

Fig. 5 Wo-En-Fs diagram (after Morimoto 1988) constructed after subtraction of all components not included in Wo-En-Fs system. a - analyses of pyroxenes from basaltic rocks; $b$ - analyses of pyroxenes from picrobasaltic rocks; $c$ - analyses of pyroxenes from essexite; $d-$ analyses of pyroxenes from tephriphonolite. 

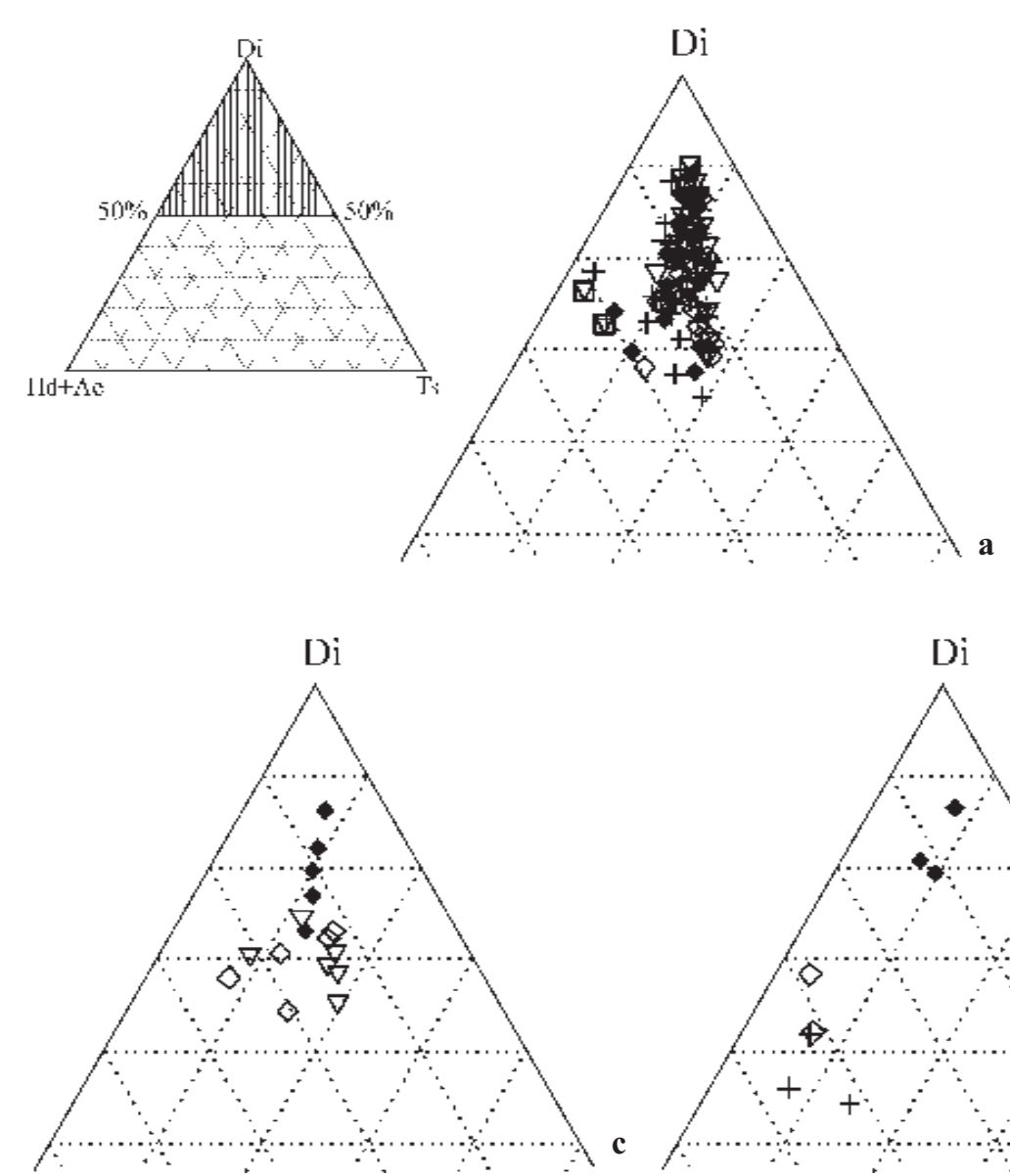

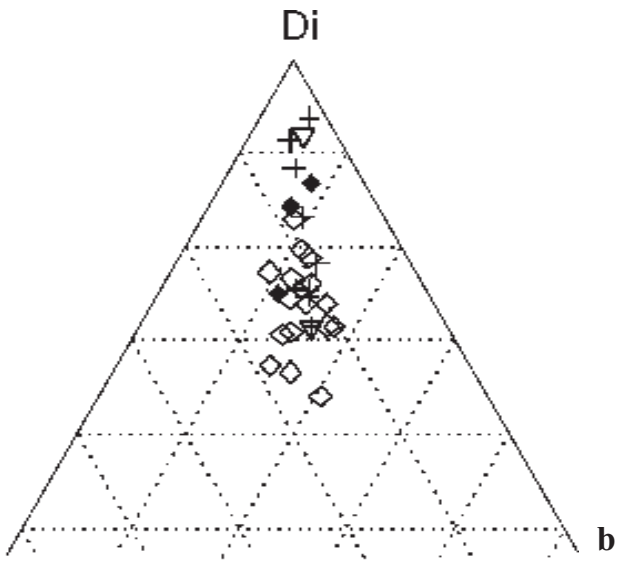

Di

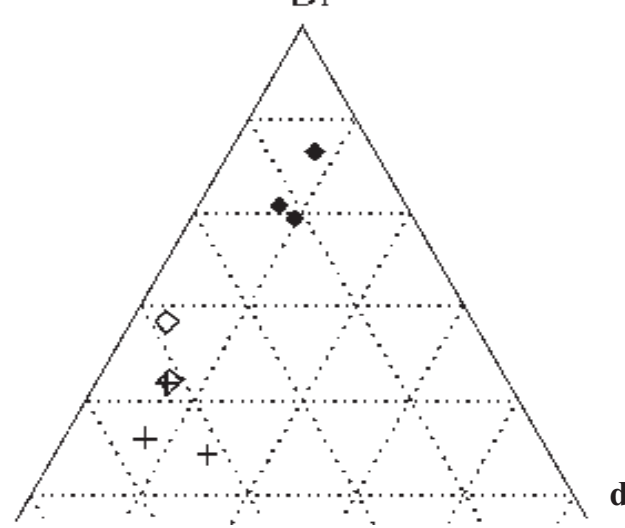

core

$\sqrt{ }$ growth zone (mantle)

Sim

+ microcryst in matrix

D glomerocryst

Fig. 6 Di-(Hd+Ae)-Ts ternary diagram (after Huckenholz 1973). Di and Hd molecules were calculated from Wo, En and Fs proportions. Ts is a total of Tschermak's molecules (CAT + CFT + CTT). a - analyses of pyroxenes from basaltic rocks; b - analyses of pyroxenes from picrobasaltic rocks; $\mathrm{c}$ - analyses of pyroxenes from essexite; $\mathrm{d}$ - analyses of pyroxenes from tephriphonolite.

\section{Data recalculation}

As augite and diopside crystallize both in the same C2/c space group (Cameron - Papike 1981, 1982), their distinction in modern mineralogical classification (Morimoto 1988) is based on chemical composition. Therefore, terminology of clinopyroxenes from the DHVC should be based on mineral chemistry.

Number of atoms per formula unit was calculated on 4 cations. Method of Vieten and Hamm (1978) balancing the deficiency of oxygen atoms corresponding to 4 cations (with all iron as $\mathrm{Fe}^{2+}$ ) was used for calculation of $\mathrm{Fe}^{3+}$.

Crystal-chemical formulas $\left(\mathrm{M}_{2}{ }_{1} \mathrm{M}_{1} \mathrm{~T}_{2} \mathrm{O}_{6}\right)$ have been derived by successive filling of structural positions (Cameron - Papike 1981, 1982, Morimoto 1988). Si and Al solely enter the T-site according the practice of Cameron and Papike, whereas Huckenholz et al. (1969) proved possible presence of $\mathrm{Fe}^{3+}$ in this position. On the basis of information by Huckenholz et al. (1969), IMA recommends inclusion of $\mathrm{Fe}^{3+}$ into $\mathrm{T}$-site in cases when it is needed (Morimoto 1988). Due to insufficient contents of Si and $\mathrm{Al}$ in some cases of clinopyroxenes from the DHVC, IMA recommendation was accepted. Distribution of individual metals among the three mentioned sites has been done in self-prepared MS Excel spreadsheet. Numbers of atoms per formula unit (apfu) are presented in Tables 2, 3 and 4 for representative samples or on journal website as complete dataset (together with complete analytical data).

For classification of pyroxenes, recommendations of the International Mineralogical Association (IMA) were followed (Moritmoto 1988). According to the J-Q diagram (Fig. 3), all analyzed clinopyroxenes belong to the "Quad" field and none of them (neither from tephriphonolite) plotted in Na-Ca field. High contents of Ca-Al-Tschermak's and Ca-Ti-Tschermak's molecules prevented a direct use of Wo-En-Fs quadrilateral diagram, because the analyses would plot high above the $\mathrm{Wo}=50 \%$ line, even though in only few cases $\mathrm{Ca}$ content is in excess. The effect of overestimation of the Wo component in the Wo-En-Fs diagram can be evaded using $\mathrm{Fe} /(\mathrm{Fe}+\mathrm{Mg}$ ) / Ca diagram (Fig. 4). $\mathrm{Fe} /(\mathrm{Fe}+\mathrm{Mg}$ ) value (X-axis) is equal to $\mathrm{Fs} /(\mathrm{Fs}+\mathrm{En})$ value (sensu Morimoto 1988 - calculated with Fs based on total $\mathrm{Fe}$ ) and $\mathrm{y}$-axis shows the total number of $\mathrm{Ca}$ apfu (the range of y-axis 0.00-2.00 was used for good comparison with Wo-En-Fs diagram; wollastonite corresponds to $\mathrm{Ca}=2.00)$.

In order to obtain true ratios of molecules entering the quadrilateral diagram, the additional components (molecules) were subtracted in the following sequence: kosmochlor $\left(\mathrm{NaCrSi}_{2} \mathrm{O}_{6}\right)$, aegirine $\left(\mathrm{NaFe}^{3+} \mathrm{Si}_{2} \mathrm{O}_{6}\right)$, jade- 
ite $\left(\mathrm{NaAlSi}_{2} \mathrm{O}_{6}\right)$, kanoite $\left(\mathrm{MnMgSi}_{2} \mathrm{O}_{6}\right)$, Ca-ferri-Tschermak's molecule $\left(\mathrm{CaFe}^{3+}{ }_{2} \mathrm{SiO}_{6}\right)$, Ca-Al-Tschermak's molecule $\left(\mathrm{CaAl}_{2} \mathrm{SiO}_{6}\right)$, Ca-Ti-Tschermak's molecule $\left(\mathrm{CaTiAl}_{2} \mathrm{O}_{6}\right)$ and esseneite $\left(\mathrm{CaFe}^{3+} \mathrm{AlSiO}_{6}\right)$. The rhodonite $\left(\mathrm{Mn}_{2} \mathrm{Si}_{2} \mathrm{O}_{6}\right)$ molecule was also needed in one case. The purified WoEn-Fs system was then used for construction of quadrilateral Wo-En-Fs diagram (Fig. 5). Such procedure does not follow the IMA recommendations (Morimoto 1988), but appeared to be necessary in the study of the DHVC clinopyroxenes. Proportions of diopside and Tschermak's molecules are presented in the $\mathrm{Hd}+\mathrm{Ae}-\mathrm{Di}-\mathrm{Ts}$ diagram (after Huckenholz 1973 - Fig. 6), where di and hd contents were calculated from purified Wo-En-Fs system and Ts is sum of Tschermak's molecules.

The results of calculation have been plotted using GCDkit software (Janoušek et al. 2006) working in R-language (R Development Core Team, 2005).

\section{Results}

\section{Chemical composition of clinopyroxenes}

\section{Clinopyroxenes from basaltic rocks}

Two generations of clinopyroxene can be observed in most samples of the basaltic rocks. The first generation is represented by large phenocrysts, enclosed in finegrained matrix including clinopyroxene microcrysts of younger generation. Phenocrysts consist often of a core and one or several distinguishable growth zones. The growth zoning is mostly of a progressive character (Fig. 7) and only scarcely oscillates (Fig. 8). The general compositional trend is always characterized by decrease in $\mathrm{MgO}$ and $\mathrm{SiO}_{2}$ and increase in $\mathrm{FeO}_{\text {tot }}, \mathrm{TiO}_{2}$ and $\mathrm{Al}_{2} \mathrm{O}_{3}$ from core to margin (see Table 2). Chemical composition of the whole dataset is plotted in Figs 3, 4, 5, 6, 11 and 12. No differences in composition have been observed between prismatic and pyramidal sectors that indicate absence of sector zoning. Calculated numbers of atoms per formula unit (apfu) of representative clinopyroxenes are presented in Table 2.

The empirical formula of averaged ( $n=33$ ) clinopyroxene cores from basaltic rocks can be presented as:

$$
\left(\mathrm{Na}_{0.03} \mathrm{Ca}_{0.93} \mathrm{Fe}_{0.04}^{2+}\right)\left(\mathrm{Fe}_{0.07}^{2+} \mathrm{Mg}_{0.76} \mathrm{Ti}_{0.06} \mathrm{Fe}_{0.09}^{3+} \mathrm{Al}_{0.02}\right)\left(\mathrm{Al}_{0.20} \mathrm{Si}_{1.80}\right) \mathrm{O}_{6}
$$

and the crystal-chemical formula of averaged $(n=77)$ clinopyroxene rims and microcrysts from basaltic rocks can be presented as:

$$
\left(\mathrm{Na}_{0.04} \mathrm{Ca}_{0.93} \mathrm{Fe}_{0.03}^{2+}\right)\left(\mathrm{Fe}_{0.08}^{2+} \mathrm{Mg}_{0.71} \mathrm{Ti}_{0.09} \mathrm{Fe}_{0.11}^{3+} \mathrm{Al}_{0.01}\right)\left(\mathrm{Al}_{0.25} \mathrm{Si}_{1.75}\right) \mathrm{O}_{6}
$$

The variation in chemical composition through the phenocrysts is visible even on these averaged empirical formulas. Increase in $\mathrm{Al}, \mathrm{Ti}, \mathrm{Fe}^{\text {tot }}$ and $\mathrm{Na}$ and decrease in $\mathrm{Si}$ and $\mathrm{Mg}$ from core to rim are characteristic for clinopyroxenes in alkali basaltoids and were described from numerous areas (e.g. Dobosi 1989, Ulrych et al. 1998). In the first stage of crystallization, elements building molecule of diopside ( $\mathrm{Si}$ and $\mathrm{Mg}$ ) are preferred, in later stages struc-
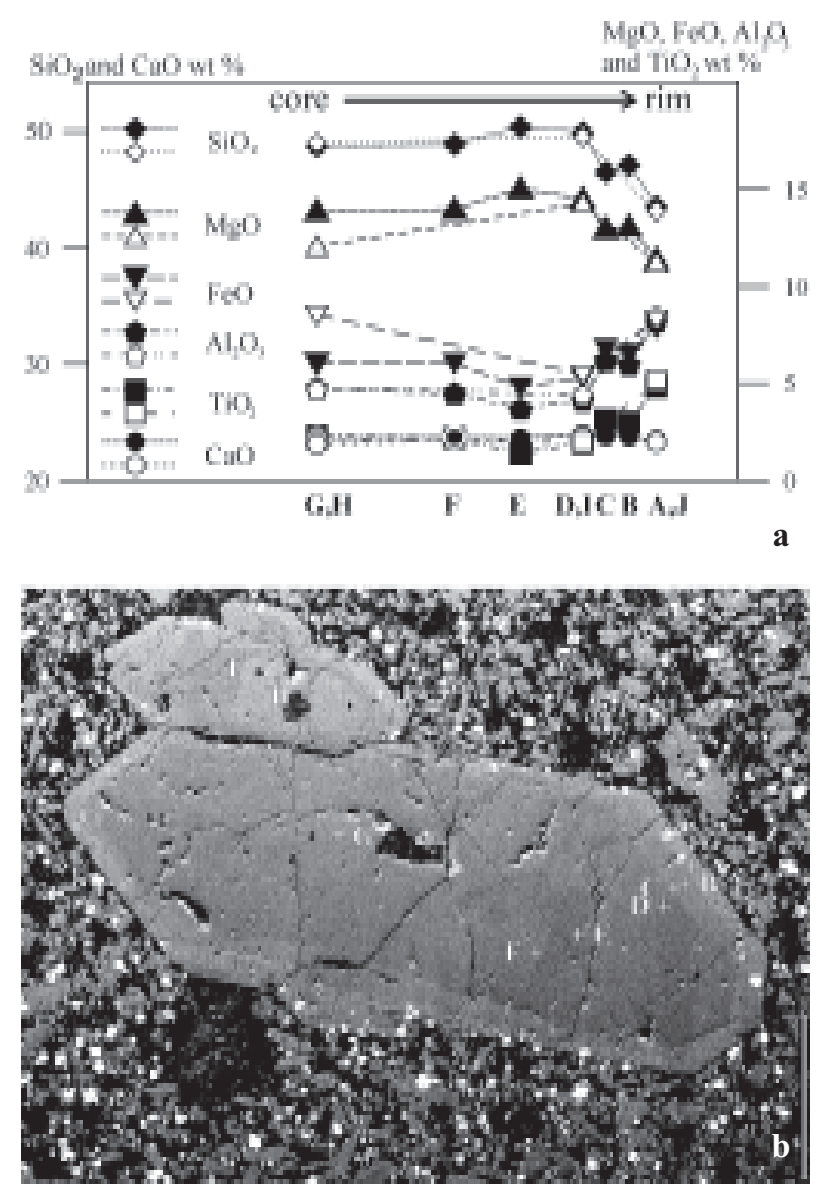

Fig. 7 a - Microprobe traverse trough a twinned clinopyroxene phenocryst (crystals 1 and 2) in the sample DH646 (analcimitic lava from the saddle between Hradiště hill and Pustý zámek hill - see Fig. 2). Solid symbols are for the larger twin, whereas open symbols are for the smaller one; $b$ - BSE image of the analyzed phenocryst. Scale bar in the right bottom corner is $500 \mu \mathrm{m}$.

ture of pyroxenes accepts also the "non-pyroxene" elements as Ti, Al and alkalis. Variations in samples DH582 and DH646 are visualized in Figs 7 and 8. The mentioned trends of decrease in $\mathrm{MgO}$ and $\mathrm{SiO}_{2}$ contents and increase in $\mathrm{FeO}_{\text {tot }}, \mathrm{TiO}_{2}$ and $\mathrm{Al}_{2} \mathrm{O}_{3}$ are well-defined, whereas $\mathrm{CaO}$ content is uniform and independent of crystallization progress. The trend of decreasing $\mathrm{MgO}$ and increasing $\mathrm{FeO}$ is dependent on decreasing temperature and differentiation of basaltic melt, where $\mathrm{FeO} / \mathrm{MgO}$ increases due to fractional crystallization (Huebner - Turnock 1980).

Clinopyroxenes from picrobasalts are very similar to those of other basaltoids. A slightly elevated $\mathrm{Mg} / \mathrm{Fe}$ ratio cannot be used as a discriminator due to a large overlap with pyroxenes from other types of basaltic rocks. The chemical composition of cores of clinopyroxenes from picrobasaltic lavas can be presented by averaged $(n=12)$ empirical formula:

$$
\left(\mathrm{Na}_{0.04} \mathrm{Ca}_{0.91} \mathrm{Fe}_{0.05}^{2+}\right)\left(\mathrm{Fe}_{0.03}^{2+} \mathrm{Mg}_{0.84} \mathrm{Cr}_{0.01} \mathrm{Ti}_{0.03} \mathrm{Fe}_{0.06}^{3+} \mathrm{Al}_{0.03}\right)\left(\mathrm{Al}_{0.11} \mathrm{Si}_{1.89}\right) \mathrm{O}_{6}
$$

whereas rims and microcrysts of clinopyroxene in picrobasalts have averaged $(\mathrm{n}=31)$ composition:

$\left(\mathrm{Na}_{0.04} \mathrm{Ca}_{0.92} \mathrm{Fe}_{0.04}^{2+}\right)\left(\mathrm{Fe}_{0.07}^{2+} \mathrm{Mg}_{0.73} \mathrm{Ti}_{0.07} \mathrm{Fe}_{0.10}^{3+} \mathrm{Al}_{0.03}\right)\left(\mathrm{Al}_{0.22} \mathrm{Si}_{1.78}\right) \mathrm{O}_{6}$ 


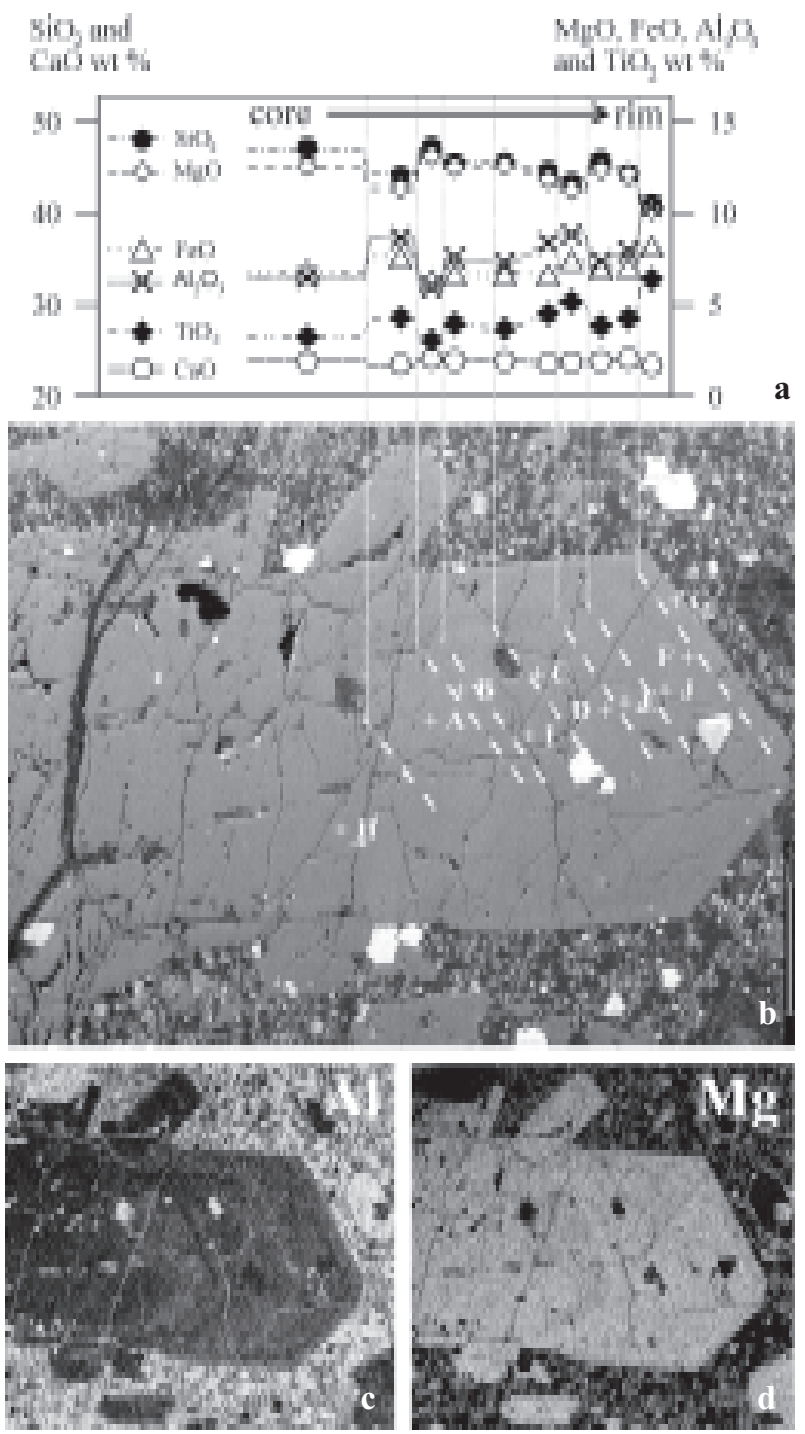

Fig. 8 a) Microprobe traverse trough zoned clinopyroxene phenocryst No. 5 in the sample DH582 (phenocryst 582-5, see analyses in Tab. 1.), which is olivine-bearing fine-grained analcimite from the northern slope of the U Tokaniště hill - south of the Pustý zámek hill (see Fig. 2). The zonation is visible on BSE image (b) and in distribution maps of aluminum (c) and magnesium (d) respectively. Scale bar in the right bottom corner of the BSE image is $500 \mu \mathrm{m}$.

Slightly higher contents of $\mathrm{Mg}$ in cores of clinopyroxenes from picrobasalts, if compared to common basaltoids, are obvious, whereas rims and microcrysts are indistinguishable from those of other basaltoids.

The picrobasalts of the DHVC are comparable to picrobasalts of Hocheifel. Clinopyroxenes show the same compositional shifts, characterized by decrease in $\mathrm{Si}, \mathrm{Mg}$ and $\mathrm{Cr}$ and increase in $\mathrm{Al}, \mathrm{Fe}^{2+}$ and $\mathrm{Ti}$ in both complexes, but all clinopyroxene generations from picrobasalts of the DHVC are richer in silica and magnesium and poorer in ferroan iron and titanium then those from Hocheifel studied by Huckenholz (1966). Calcium, sodium and chromium contents seem to be equal. On the other hand, studied picrobasaltic clinopyroxenes and observed trends are very similar to those analyzed by Scott
(1976) from ankaramites of Tenerife. Similar crystallization trend was also described from ancient alkaline basalts from Mt. Etna (Nazzareni et al. 2003), where pyroxenes have chromium-rich cores. Their rims differ from picrobasaltic pyroxenes from the DHVC in lower contents of titanium.

Clinopyroxenes from olivine melilitite-(polzenite)nephelinite suite from the Ploučnice region (NNE Bohemia) are characterized by extremely low Si and high Al and Ti contents (Ulrych et al. 1990, 1991). Also Mg content is much lower than in pyroxenes of picrobasaltic rocks from the DHVC. Clinopyroxenes from basaltoids of the České středohoří Volcanic Complex (Ulrych 1986) are chemically closer to the DHVC, but mostly differ in higher $\mathrm{Fe}^{\mathrm{tot}} / \mathrm{Mg}$.

Clinopyroxenes in the studied basaltic rocks of the DHVC are classified as diopside following the IMA rules modified with subtraction of the additional components prior to construction of Wo-En-Fs diagram as mentioned above. Their content of aluminium, which is always far above classification limit ( $>0.1$ apfu - Morimoto 1988), results in use of the qualifier "aluminian". The content of Ti in clinopyroxene rims from basaltoids is also slightly higher than the limit of 0.1 apfu and in such cases specifies the term with modifier titanian. The full designation of clinopyroxenes in basaltic rocks of DHVC is then $( \pm t i$ tanian) aluminian diopside. On the other hand, titanium content in clinopyroxene cores from picrobasalts is low and partly compensated by chromium. Such clinopyroxenes should be called chromian aluminian diopside.

\section{Clinopyroxenes from essexitic rock}

Clinopyroxenes occur predominantly as large phenocrysts, forming more than 60 vol.\% of the rock, whereas in matrix they are relatively rare. Variation in chemical composition through growth zones of studied phenocrysts is of the same character as in basaltic lavas. Also here, a decrease in $\mathrm{MgO}$ and $\mathrm{SiO}_{2}$ and increase in $\mathrm{FeO}, \mathrm{TiO}_{2}$ and $\mathrm{Al}_{2} \mathrm{O}_{3}$ with ongoing crystallization have been observed (Fig. 9). Such compositional shift corresponds to increase in contents of aegirine and Tschermak's molecules (Fig. 6). Numerically is the compositional shift expressed in difference between averaged empirical formula of the cores $(n=5)$ :

$$
\left(\mathrm{Na}_{0.03} \mathrm{Ca}_{0.95} \mathrm{Fe}_{0.02}^{2+}\right)\left(\mathrm{Fe}_{0.08}^{2+} \mathrm{Mg}_{0.73} \mathrm{Ti}_{0.08} \mathrm{Fe}_{0.10}^{3+} \mathrm{Al}_{0.01}\right)\left(\mathrm{Al}_{0.24} \mathrm{Si}_{1.76}\right) \mathrm{O}_{6}
$$

and growth zones and rims of clinopyroxene phenocrysts $(\mathrm{n}=10)$ :

$$
\left(\mathrm{Na}_{0.04} \mathrm{Ca}_{0.95} \mathrm{Fe}_{0.01}^{2+}\right)\left(\mathrm{Fe}_{0.12}^{2+} \mathrm{Mg}_{0.64} \mathrm{Ti}_{0.10} \mathrm{Fe}_{0.11}^{3+} \mathrm{Al}_{0.03}\right)\left(\mathrm{Al}_{0.30} \mathrm{Si}_{1.70}\right) \mathrm{O}_{6}
$$

Clinopyroxene phenocrysts in essexite do not show sector zoning and compositionally correspond to clinopyroxenes from weakly evolved basaltoids, such as tephrites (Fig. 4).

Chemical composition of clinopyroxenes from essexitic rocks of the České středohoří Mts. was studied by Ulrych (1983, 1998). Clinopyroxenes from monzodior- 

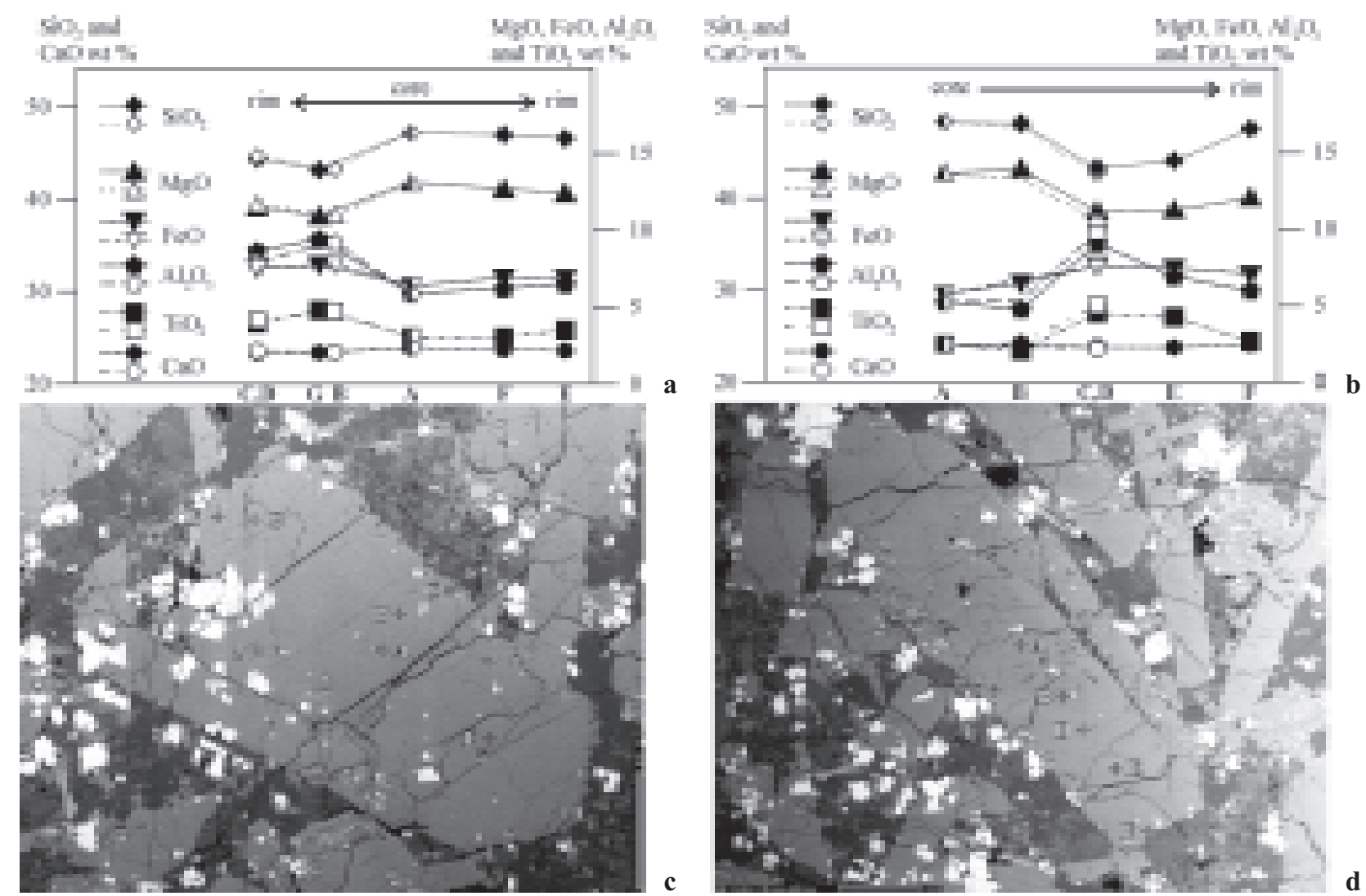

Fig. 9 a, b - Microprobe traverse trough the phenocrysts 1 and 4, respectively, of the sample KA43 (essexite from the Donín Valley); c, d-showing BSE images of analyzed phenocrysts with location of the analyzed spots. Solid symbols were used for pyramidal sectors, whereas open ones for prismatic sectors. Scale bars (both $1 \mathrm{~mm}$ ) are in right bottom corner and left bottom corner, respectively.

ite (rongstockite), essexites and sodalite syenites of the České středohoří Mts. are generally richer in $\mathrm{Si}$ and $\mathrm{Mg}$ and poorer in $\mathrm{Al}$ and $\mathrm{Ti}$, if compared with clinopyroxenes from essexite of the DHVC. Higher amount of Al and Ti is most probably related to a shallower depth of exposed essexitic intrusion in the DHVC. Increasing content of $\mathrm{CaTiAl}_{2} \mathrm{O}_{6}$ molecule in diopside dependent on decreasing pressure were described by Yagi - Onuma (1967), Wass (1979) a.o.

\section{Clinopyroxenes from tephriphonolitic rock}

Clinopyroxenes in studied tephriphonolitic rock occur in two clearly defined generations. Colorless to weakly brownish (in thin section) cores are overgrown by remarkable green rims. Commonly, clinopyroxenes are spatially associated with brown amphiboles (which occur also individually). The $\mathrm{MgO} /(\mathrm{MgO}+\mathrm{FeO})$ molar ratio in amphibole in the core of large clinopyroxene phenocryst (Fig. 10) is much lower (c. 0.55), then in core of clinopy- roxene (c. 0.8 ) and also lower than in clinoyproxene rim (c. 0.66). The amphibole phenocryst accreted to the clinopyroxene in Fig. 10 (top right - with reaction rim) is even poorer in $\mathrm{MgO}$. The petrogenetic significance of the amphibole inclusion within clinopyroxene is not clarified yet.

Chemical composition of cores of the clinopyroxene phenocrysts from DH796 tephriphonolite is similar to composition of clinopyroxenes from basaltic rocks (Figs 5 and 6$)$. Their averaged composition $(n=3)$ corresponds to the empirical formula:

$$
\left(\mathrm{Na}_{0.04} \mathrm{Ca}_{0.93} \mathrm{Fe}_{0.03}^{2+}\right)\left(\mathrm{Fe}_{0.07}^{2+} \mathrm{Mg}_{0.76} \mathrm{Ti}_{0.06} \mathrm{Fe}_{0.09}^{3+} \mathrm{Al}_{0.02}\right)\left(\mathrm{Al}_{0.19} \mathrm{Si}_{1.81}\right) \mathrm{O}_{6}
$$

In contrast to composition of cores of phenocryst, the phenocryst rims and clinopyroxene microcrysts in matrix are of a more evolved composition (Figs 5, 10 and 12). Calculated crystal chemical formulas were averaged $(n=5)$ as follows:

$$
\left(\mathrm{Na}_{0.10} \mathrm{Ca}_{0.90}\right)\left(\mathrm{Fe}_{0.20}^{2+} \mathrm{Mg}_{0.56} \mathrm{Ti}_{0.05} \mathrm{Fe}_{0.16}^{3+} \mathrm{Al}_{0.03}\right)\left(\mathrm{Al}_{0.18} \mathrm{Si}_{1.82}\right) \mathrm{O}_{6}
$$

Table 2 Analyses, calculated numbers of atoms per formula unit and proportions of end-members of pyroxenes from representative basaltic rocks. "s" - core; "z" - growth zone (mantle); "o" - rim; "d" - microcrysts in matrix. Content of oxides is in wt.\%.

ko $=$ kosmochlor; ae = aegirine; $\mathrm{jd}=$ jadeite; $\mathrm{ka}=$ kanoite; CFT $=\mathrm{Ca}-$ ferri-Tschermak's molecule; CAT $=$ Ca-Tschermak's molecule; $\mathrm{CTT}=\mathrm{Ca}-\mathrm{Ti}$-Tschermak's molecule; ess = esseneite; en = enstatite; fs = ferrosilite; wo = wollastonite. Abbreviations correspond to IMA (Morimoto et al. 1988, Martin 1998). 


\begin{tabular}{|c|c|c|c|c|c|c|c|}
\hline & 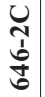 & & 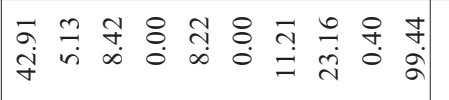 & $\begin{array}{lll}n & 0 \\
m & 0 \\
0 & 0 \\
0 & 0\end{array}$ & 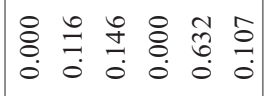 & $\hat{\widehat{O}}$ & $\left.\begin{array}{c}0 \\
0\end{array}\right]$ \\
\hline & 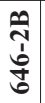 & & 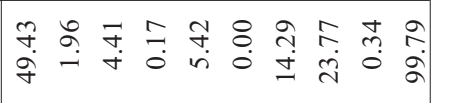 & $\mid \begin{array}{ccc}0 & 0 \\
0 & 0 & 0 \\
0 & 0\end{array}$ & 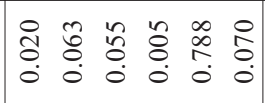 & 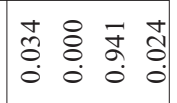 & 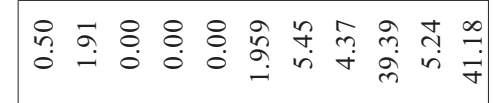 \\
\hline & 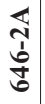 & & 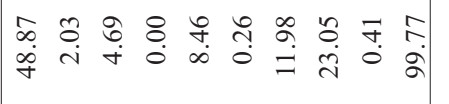 & 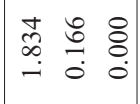 & 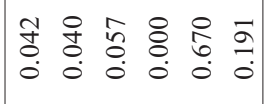 & $\begin{array}{llll}\varkappa & \infty & 0 \\
\hat{\sigma} & 0 & 0 & 0 \\
0 & 0 & 0 \\
0 & 0 & 0 \\
0\end{array}$ & 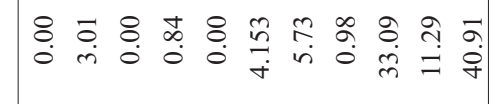 \\
\hline & 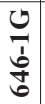 & & 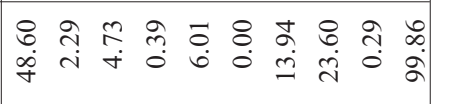 & 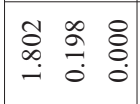 & 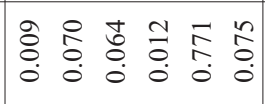 & $\mid \begin{array}{llll}1 & 0 & 0 \\
0 & 0 & \hat{0} & 0 \\
0 & 0 & 0 & 0 \\
0\end{array}$ & 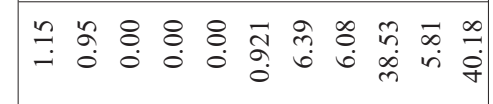 \\
\hline & 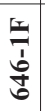 & & 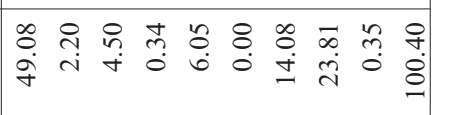 & $\begin{array}{ccc}0 & \overrightarrow{0} & 0 \\
\infty & \overrightarrow{7} & \vdots \\
-\rightarrow & 0 & 0\end{array}$ & 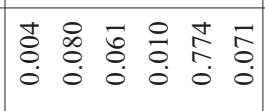 & $\mid \begin{array}{llll}n & 0 & 0 \\
0 & 0 & 0 & 0 \\
0 & 0 & 0 \\
0 & 0 & 0 \\
0\end{array}$ & ڤેे \\
\hline & 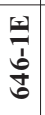 & & 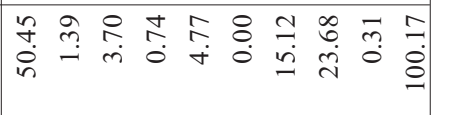 & $\begin{array}{ll}\infty & 0 \\
\stackrel{1}{0} & \vdots \\
0 & 0 \\
0\end{array}$ & 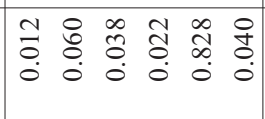 & 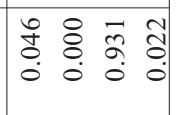 & 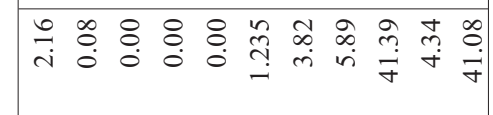 \\
\hline & 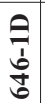 & & 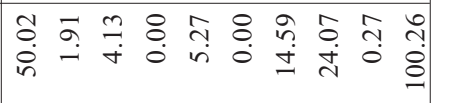 & \begin{tabular}{lll|} 
& $\vec{b}$ & 8 \\
\hdashline & $\stackrel{0}{0}$ & 0 \\
- & 0 & 0
\end{tabular} & 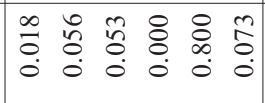 & 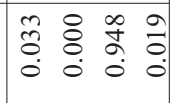 & \& \\
\hline & 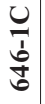 & & 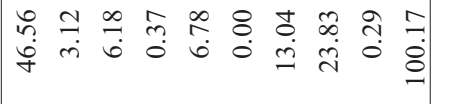 & $\begin{array}{ccc}\vec{n} & 0 \\
0 & 0 \\
0 & 0\end{array}$ & $\frac{1}{0}$ & $\vec{m}$ & 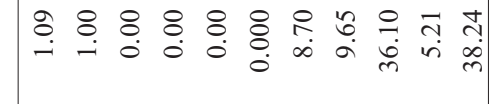 \\
\hline & 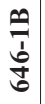 & & 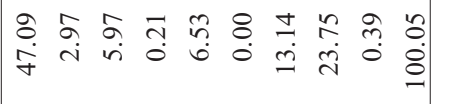 & $\begin{array}{ll}1 & 0 \\
& \vdots \\
0 & 0 \\
0 & 0\end{array}$ & $\mid \begin{array}{lll}0 & 0 \\
\delta & 0 & 0 \\
0 & 0 \\
0 & 0 & 0 \\
0 & 0 \\
0\end{array}$ & $\begin{array}{llll}\infty & 0 & \infty \\
0 & 0 & 0 & 0 \\
0 & 0 & 0 & 0 \\
0 & 0 & 0\end{array}$ & 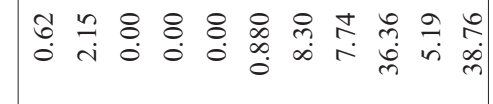 \\
\hline & 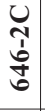 & & 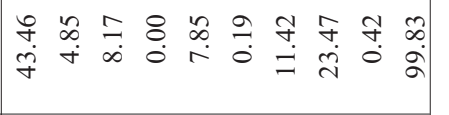 & $\begin{array}{ll}\tilde{0} & n \\
0 & 0 \\
0 & 0 \\
0 & 0\end{array}$ & $\stackrel{8}{\circ}$ & $\begin{array}{ll}0 \\
\partial \\
0 & 8 \\
0 & 0\end{array}$ & 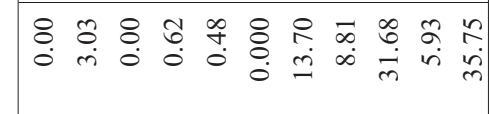 \\
\hline & 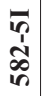 & & 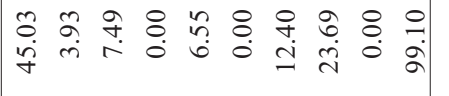 & $\mid \begin{array}{ll}0 & 0 \\
0 & 0 \\
0 & 0 \\
0 & 0\end{array}$ & $\begin{array}{lll}\text { बें } & \overline{0} & \Xi \\
0 & 0 & 0 \\
0\end{array}$ & 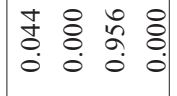 & 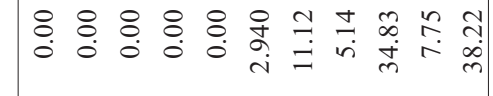 \\
\hline & 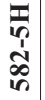 & & 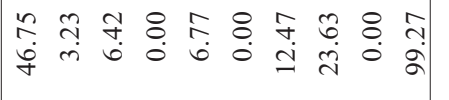 & 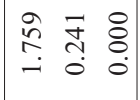 & 萡 & 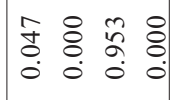 & 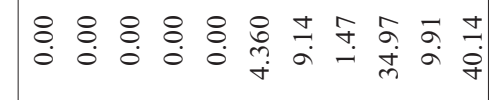 \\
\hline & 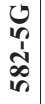 & & 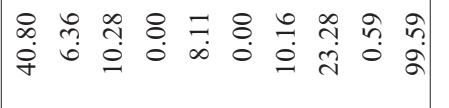 & 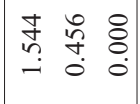 & 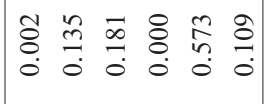 & $\begin{array}{llll}m & 0 \\
0 & 0 & 0 & 0 \\
0 & 0 & 0 & 0 \\
0\end{array}$ & \& \\
\hline & 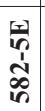 & & 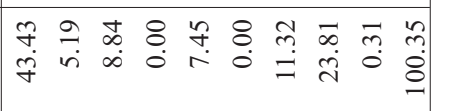 & 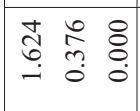 & 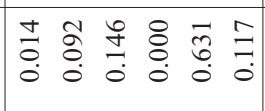 & 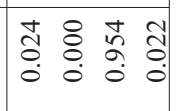 & \& \\
\hline & 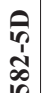 & & 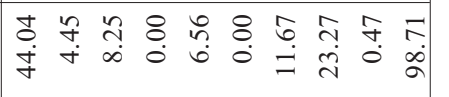 & $\begin{array}{lll} & 0 & 0 \\
0 & 0 & 0 \\
-1 & \ddots & \vdots \\
- & 0 & 0\end{array}$ & $\begin{array}{ll}\tilde{N} & 0 \\
\tilde{\delta} & 0 \\
0 & 0 \\
0 & 0\end{array}$ & 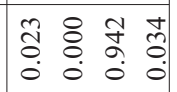 & 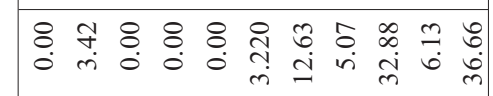 \\
\hline$\theta$ & 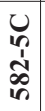 & & 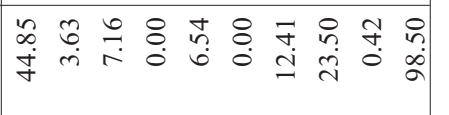 & $\mid$\begin{tabular}{lll|}
0 & 0 & 0 \\
0 & 0 & 0 \\
-1 & 0 & 0 \\
- & 0 & 0
\end{tabular} & 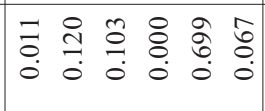 & $\mid$\begin{tabular}{llll}
\multirow{\partial}{*}{} & 0 & 0 & 0 \\
0 & 0 & 0 \\
0 & 0 & 0 & 0 \\
0
\end{tabular} & 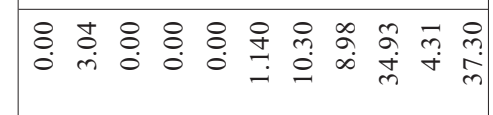 \\
\hline & 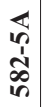 & & 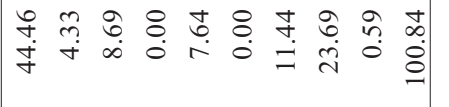 & 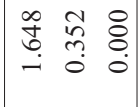 & 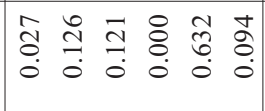 & : : & 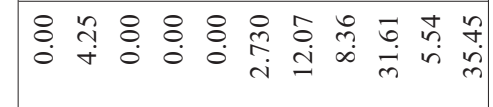 \\
\hline & 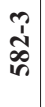 & $=$ & 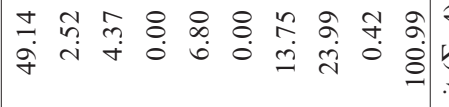 & 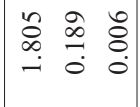 & \begin{tabular}{llll}
0 & $n$ & 0 & 0 \\
\hdashline & 0 & 0 & 0 \\
0 & 0 & 0 & 0 \\
0 & 0 & 0
\end{tabular} & 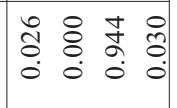 & 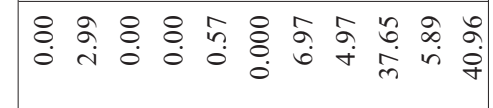 \\
\hline & 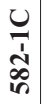 & & 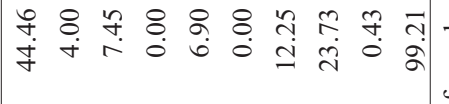 & 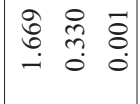 & 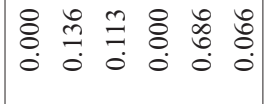 & $\left|\begin{array}{lll} \pm & 0 & n \\
0 & 0 & 0 \\
0 & 0 & 0 \\
0 & 0 & 0 \\
0\end{array}\right|$ & 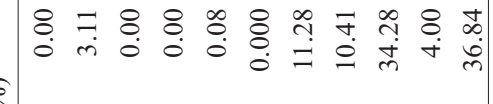 \\
\hline & 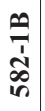 & & 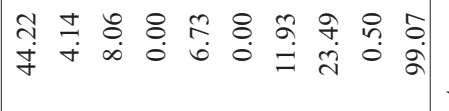 & 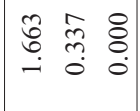 & 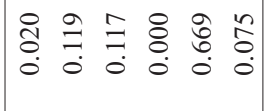 & 둥 & 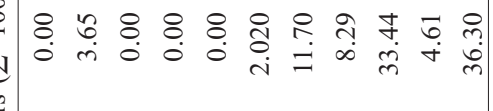 \\
\hline & 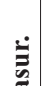 & & & & 索 & 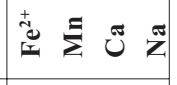 & \\
\hline$=$ & & & & & & & 已 \\
\hline
\end{tabular}


Table 3 Analyses, calculated numbers of atoms per formula unit and proportions of end-members of pyroxenes from essexite (KA-43).

\begin{tabular}{|c|c|c|c|c|c|c|c|}
\hline & & & 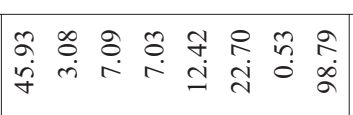 & 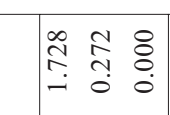 & 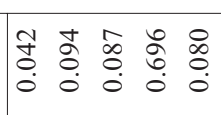 & 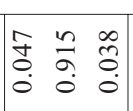 & 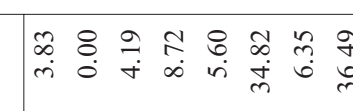 \\
\hline & \pm & & 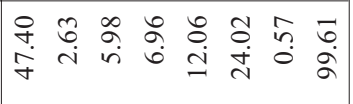 & \begin{tabular}{lll}
\multirow{1}{*}{} & ते & 8 \\
- & 0 & 0 \\
\end{tabular} & 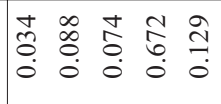 & $\mid \begin{array}{lll}0 & 0 \\
0 & 0 & 0 \\
0 & 0 & 0 \\
0 & 0 & 0\end{array}$ & 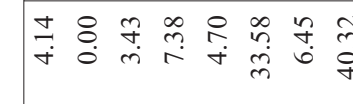 \\
\hline & 琶 & & 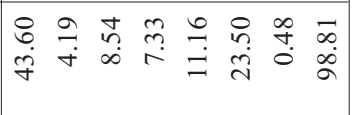 & 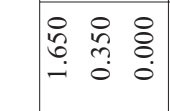 & $\begin{array}{lllll}\overrightarrow{0} & 0 & 0 & 0 & 0 \\
0 & 0 & 0 \\
0 & 0 & 0 & 0 \\
0 & 0 & 0 & 0\end{array}$ & $\begin{array}{lll}\tilde{y} & n & n \\
0 & n & 0 \\
0 & 0 & 0 \\
0\end{array}$ & 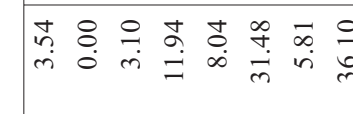 \\
\hline & 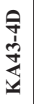 & & 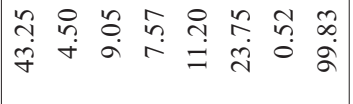 & 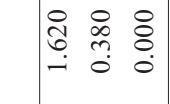 & 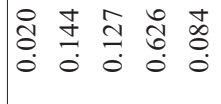 & 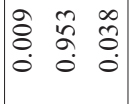 & 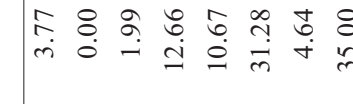 \\
\hline & 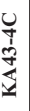 & & 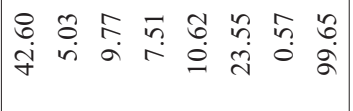 & 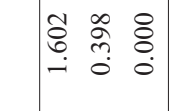 & 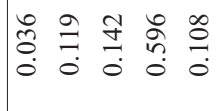 & 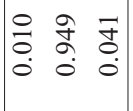 & 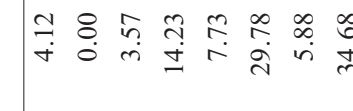 \\
\hline & & & 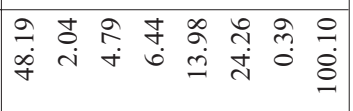 & 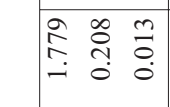 & 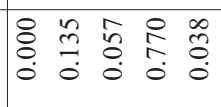 & $\begin{array}{lll}m & 0 & 0 \\
0 & 0 & 0 \\
0 & 0 & 0 \\
0 & 0 & 0\end{array}$ & 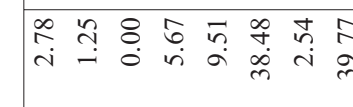 \\
\hline & $\begin{array}{l}\frac{\pi}{4} \\
\frac{3}{3}\end{array}$ & & 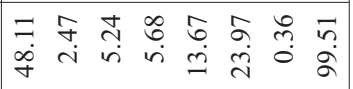 & 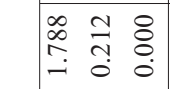 & 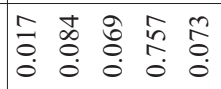 & 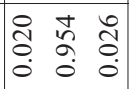 & 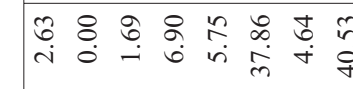 \\
\hline 9 & & & 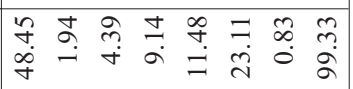 & 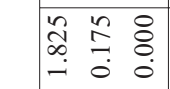 & 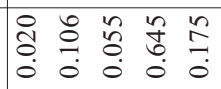 & $\begin{array}{lll}\hat{\delta} & \cdots & o \\
0 & 0 & 0 \\
0 & 0 & 0\end{array}$ & 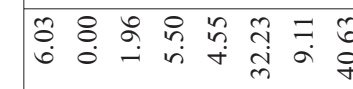 \\
\hline & 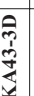 & & 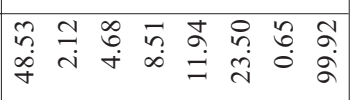 & \begin{tabular}{lll}
$n$ & $\infty$ & 0 \\
\hdashline & $\infty$ & 0 \\
$-\infty$ & 0 & 0 \\
-1 & 0 \\
0
\end{tabular} & 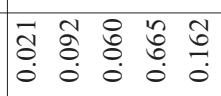 & 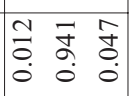 & 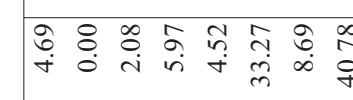 \\
\hline & ల్ల & & 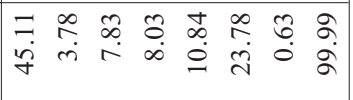 & 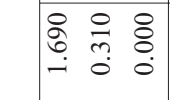 & $\begin{array}{lllll}0 & 0 & 0 & 0 \\
0 & 0 & 0 \\
0 & 0 & 0 & 0 \\
0 & 0 & 0 & 0 & 0 \\
0 & 0 & 0 \\
0\end{array}$ & $\begin{array}{lll}8 & n & 0 \\
\vdots & 0 & 0 \\
0 & 0 & 0 \\
0 & 0 & 0\end{array}$ & 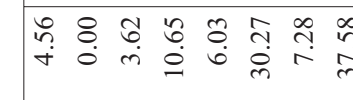 \\
\hline & 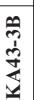 & & 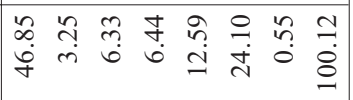 & 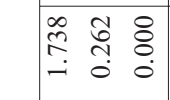 & $\begin{array}{llll}n & n & \bar{a} & 0 \\
0 & 0 & 0 & 0 \\
0 & 0 & 0 & 0 \\
0 & 0 & 0 & 0 \\
0\end{array}$ & 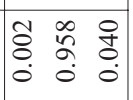 & 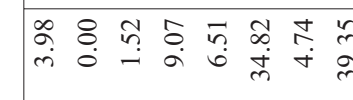 \\
\hline & 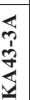 & & 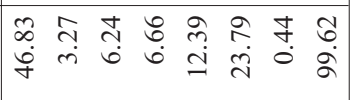 & 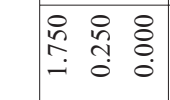 & 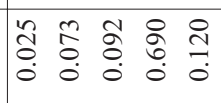 & 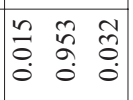 & 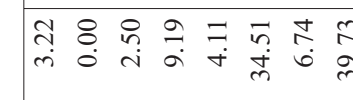 \\
\hline & $\exists$ & & 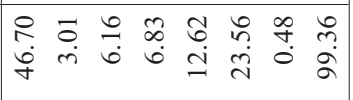 & 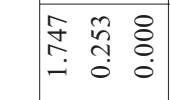 & 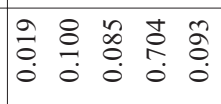 & 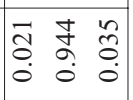 & 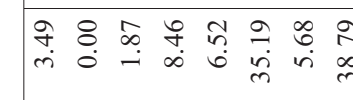 \\
\hline & $\underline{Y}$ & & 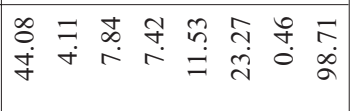 & 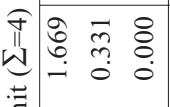 & 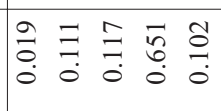 & 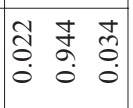 & 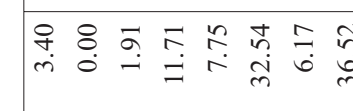 \\
\hline & $\stackrel{\oplus}{7}$ & & 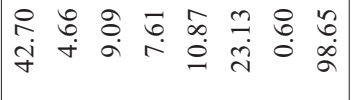 & 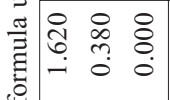 & 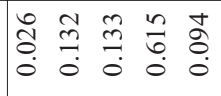 & 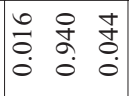 & 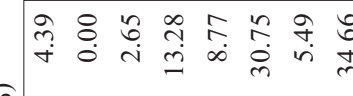 \\
\hline & 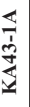 & & 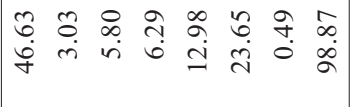 & 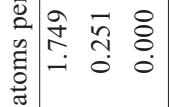 & 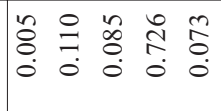 & 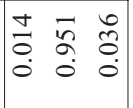 & 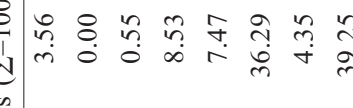 \\
\hline 产 & & & & $\left.\begin{array}{l}0 \\
0 \\
0 \\
0 \\
0\end{array}\right)=$ & $\gtrless^{+}$ & & \\
\hline & & & & 言 & $z$ & $z$ & 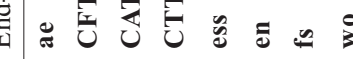 \\
\hline
\end{tabular}


Table 4 Analyses, calculated numbers of atoms per formula unit and proportions of end-members of pyroxenes from tephriphonolite (DH796).

\begin{tabular}{|c|c|c|c|c|c|c|c|c|c|}
\hline \multirow{2}{*}{\multicolumn{2}{|c|}{$\begin{array}{l}\text { rock smpl. } \\
\text { measur. }\end{array}$}} & \multicolumn{8}{|c|}{ DH796 } \\
\hline & & $796-1 \mathrm{~A}$ & $796-2 A$ & 796-3A & 796-3B & 796-4A & $796-5 A$ & $796-6 \mathrm{~A}$ & 796-6B \\
\hline \multicolumn{2}{|c|}{ min. zone } & d & d & $\mathbf{s}$ & o & $\mathbf{s}$ & d & $\mathbf{s}$ & $\mathbf{0}$ \\
\hline \multicolumn{2}{|c|}{$\mathrm{SiO}_{2}$} & 44.82 & 48.68 & 49.83 & 49.70 & 49.09 & 47.18 & 47.47 & 49.52 \\
\hline \multicolumn{2}{|c|}{$\mathrm{TiO}_{2}$} & 4.46 & 0.97 & 1.87 & 0.97 & 1.99 & 1.30 & 2.45 & 0.82 \\
\hline \multicolumn{2}{|c|}{$\mathrm{Al}_{2} \mathrm{O}_{3}$} & 6.95 & 4.00 & 4.12 & 4.18 & 4.62 & 5.09 & 5.36 & 3.11 \\
\hline \multicolumn{2}{|c|}{ FeO } & 11.61 & 11.15 & 5.32 & 11.48 & 6.50 & 13.24 & 6.63 & 10.30 \\
\hline \multicolumn{2}{|c|}{ MgO } & 9.07 & 10.22 & 14 & 10.49 & 14.05 & 8.87 & 13.00 & 11.27 \\
\hline \multicolumn{2}{|c|}{$\mathrm{CaO}$} & 21.64 & 22.55 & 23.96 & 22.50 & 23.39 & 21.81 & 23.13 & 22.33 \\
\hline \multicolumn{2}{|c|}{$\mathrm{Na}_{2} \mathrm{O}$} & 1.49 & 1.13 & 0.60 & 1.36 & 0.40 & 1.53 & 0.64 & 1.28 \\
\hline \multicolumn{2}{|c|}{ total } & 100.03 & 98.70 & 99.71 & 100.69 & 100.03 & 99.01 & 98.67 & 98.63 \\
\hline \multicolumn{10}{|c|}{ Numbers of atoms per formula unit $\left(\sum=4\right)$} \\
\hline \multirow[t]{2}{*}{$\mathbf{T}$} & Si & 1.697 & 1.854 & 1.841 & 1.852 & 1.814 & 1.801 & 1.782 & 1.875 \\
\hline & Al & 0.303 & 0.146 & 0.159 & 0.148 & 0.186 & 0.199 & 0.218 & 0.125 \\
\hline \multirow{5}{*}{ M1 } & Al & 0.007 & 0.033 & 0.021 & 0.036 & 0.016 & 0.030 & 0.019 & 0.014 \\
\hline & $\mathrm{Fe}^{3+}$ & 0.152 & 0.141 & 0.077 & 0.156 & 0.088 & 0.207 & 0.107 & 0.158 \\
\hline & $\mathbf{T i}$ & 0.127 & 0.028 & 0.052 & 0.027 & 0.055 & 0.037 & 0.069 & 0.023 \\
\hline & Mg & 0.512 & 0.580 & 0.772 & 0.583 & 0.774 & 0.505 & 0.727 & 0.637 \\
\hline & $\mathrm{Fe}^{2+}$ & 0.203 & 0.214 & 0.078 & 0.198 & 0.067 & 0.216 & 0.078 & 0.168 \\
\hline \multirow{3}{*}{ M2 } & $\mathrm{Fe}^{2+}$ & 0.013 & 0.000 & 0.009 & 0.003 & 0.046 & 0.000 & 0.024 & 0.000 \\
\hline & $\mathrm{Ca}$ & 0.878 & 0.920 & 0.948 & 0.898 & 0.926 & 0.892 & 0.930 & 0.906 \\
\hline & $\mathrm{Na}$ & 0.109 & 0.083 & 0.043 & 0.098 & 0.028 & 0.113 & 0.046 & 0.094 \\
\hline \multicolumn{10}{|c|}{ End-members $\left(\sum=100 \%\right)$} \\
\hline \multicolumn{2}{|l|}{ ae } & 10.91 & 8.35 & 4.27 & 9.84 & 2.83 & 11.31 & 4.62 & 9.39 \\
\hline \multicolumn{2}{|c|}{ CAT } & 0.67 & 3.31 & 2.05 & 3.56 & 1.57 & 3.02 & 1.93 & 1.42 \\
\hline \multicolumn{2}{|c|}{ CTT } & 12.68 & 2.79 & 5.19 & 2.73 & 5.53 & 3.74 & 6.90 & 2.32 \\
\hline \multicolumn{2}{|l|}{ ess } & 4.28 & 5.74 & 3.46 & 5.79 & 5.95 & 9.36 & 6.06 & 6.40 \\
\hline \multicolumn{2}{|l|}{ en } & 25.59 & 29.02 & 38.61 & 29.14 & 38.70 & 25.24 & 36.36 & 31.83 \\
\hline \multicolumn{2}{|l|}{ fs } & 10.79 & 10.71 & 4.35 & 10.07 & 5.65 & 10.80 & 5.06 & 8.41 \\
\hline \multicolumn{2}{|l|}{ wo } & 35.07 & 40.09 & 42.07 & 38.87 & 39.78 & 36.54 & 39.06 & 40.22 \\
\hline
\end{tabular}

Note the much higher $\mathrm{Na} / \mathrm{Ca}$ and $\mathrm{Fe}^{\mathrm{tot}} / \mathrm{Mg}$ ratios in rims, if compared with cores. Lower contents of $\mathrm{Ti}$ are also significant - especially if compared with high Ti contents in rims of other types of clinopyroxenes (Fig. 11). Low titanium and aluminium contents in the rims are responsible to the different trend declining away from the Ts apex in the $\mathrm{Hd}+\mathrm{Ae}-\mathrm{Di}-\mathrm{Ts}$ diagram (Fig. 6), if compared with basaltic rocks. Solubility of the $\mathrm{CaTiAl}_{2} \mathrm{O}_{6}$ in the diopside was in this case controlled by silica content of the magma, increasing with the differentiation. With the increasing $\mathrm{SiO}_{2}$ content, the diopside- $\mathrm{CaTiAl} \mathrm{O}_{6}$ solubility decreases (Gupta et al. 1973).

If the compositions of cores and rims of these phenocrysts are compared, it becomes obvious, that crystallization of clinopyroxene phenocrysts initiated from melt of basaltic composition with crystal chemistry similar to basaltic diopsides and continued in differentiated melt (of tephriphonolitic composition), by crystallization of clinopyroxene with higher $\mathrm{FeO}$, $\mathrm{NaO}$ and low $\mathrm{TiO}_{2}$ contents (Figs 10, 11 and 12). Crystallization and differentiation history of DH796 tephriphonolite is thus well recorded in clinopyroxene phenocrysts.

The content of sodium, which differ from pyroxenes in basaltic rocks, influenced the classification of pyroxenes crystallized from

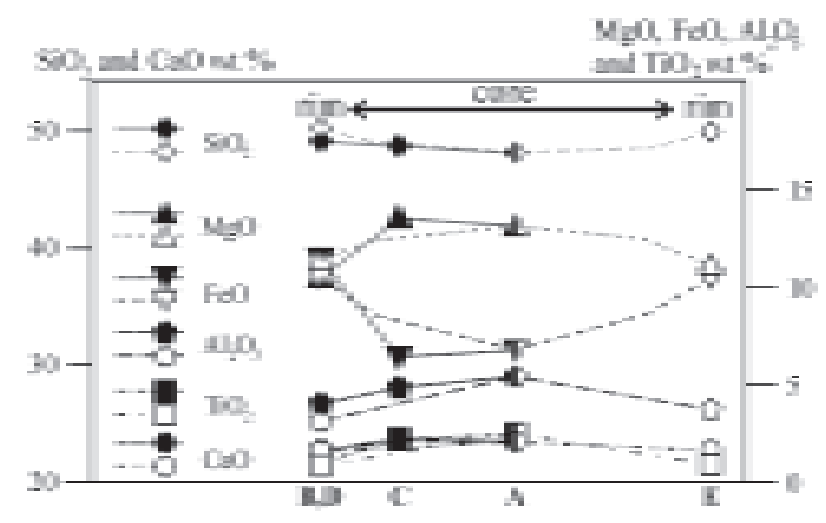

a

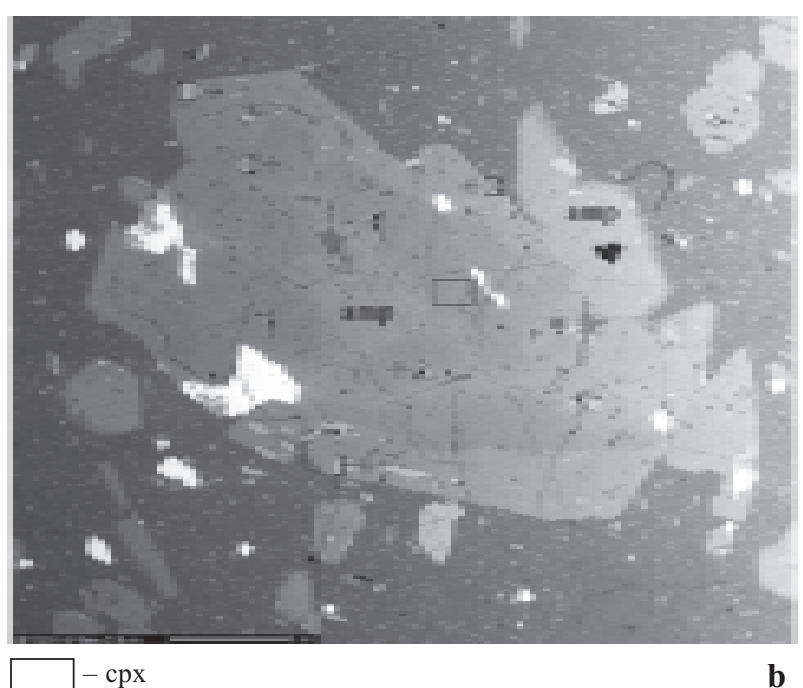

b

Fig. 10 Microprobe traverse trough the cpx phenocrysts 6 in the sample DH796 (tephriphonolite of the Herrmanov dike). Scale bar (1 mm) is in the left bottom corner. 


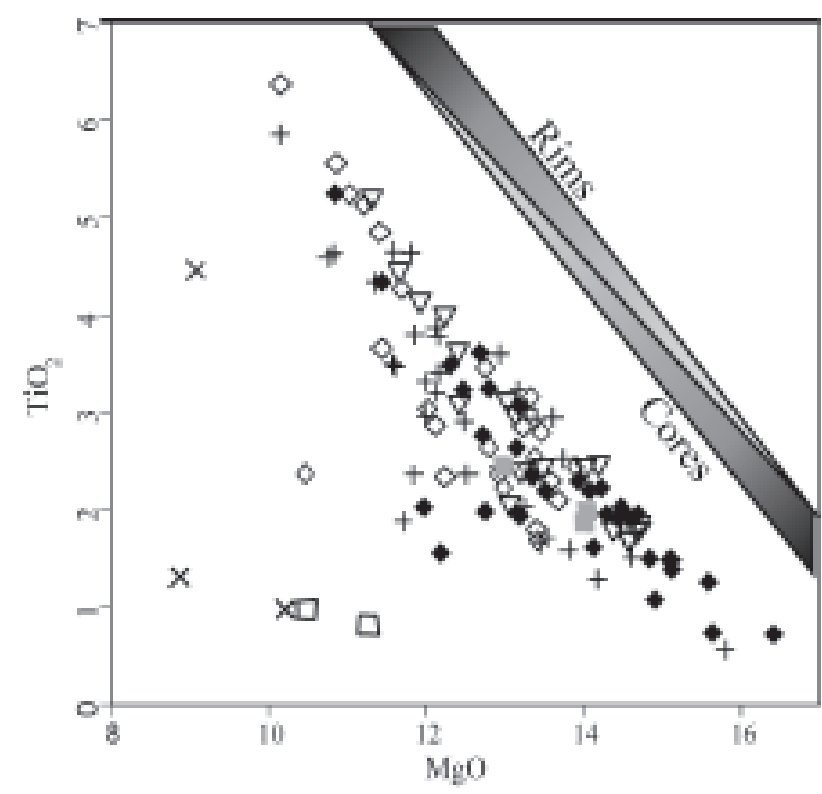

- core (basaltic rocks)

$\nabla \quad$ mantle (basaltic rocks)

$\diamond$ rim (basaltic rocks)

+ mocrocryst (basaltic rocks)

en (tephriphonolite)

D rim (tephriphonolite)

$\times$ microcryst in martix (tephriphonolite)

Fig. $11 \mathrm{MgO} / \mathrm{TiO}_{2}$ diagram for clinopyroxenes from basaltic rocks and tephriphonolite. Note the general trend in $\mathrm{TiO}_{2}$ enrichment and $\mathrm{MgO}$ depletion in direction from cores of phenocrysts to their rims. Clinopyroxene cores from tephriphonolite are compositionally very close to clinopyroxenes from basaltic rocks, whereas their rims and microcrysts in matrix are characterized by low $\mathrm{MgO}$ and low $\mathrm{TiO}_{2}$ values and differ significantly.
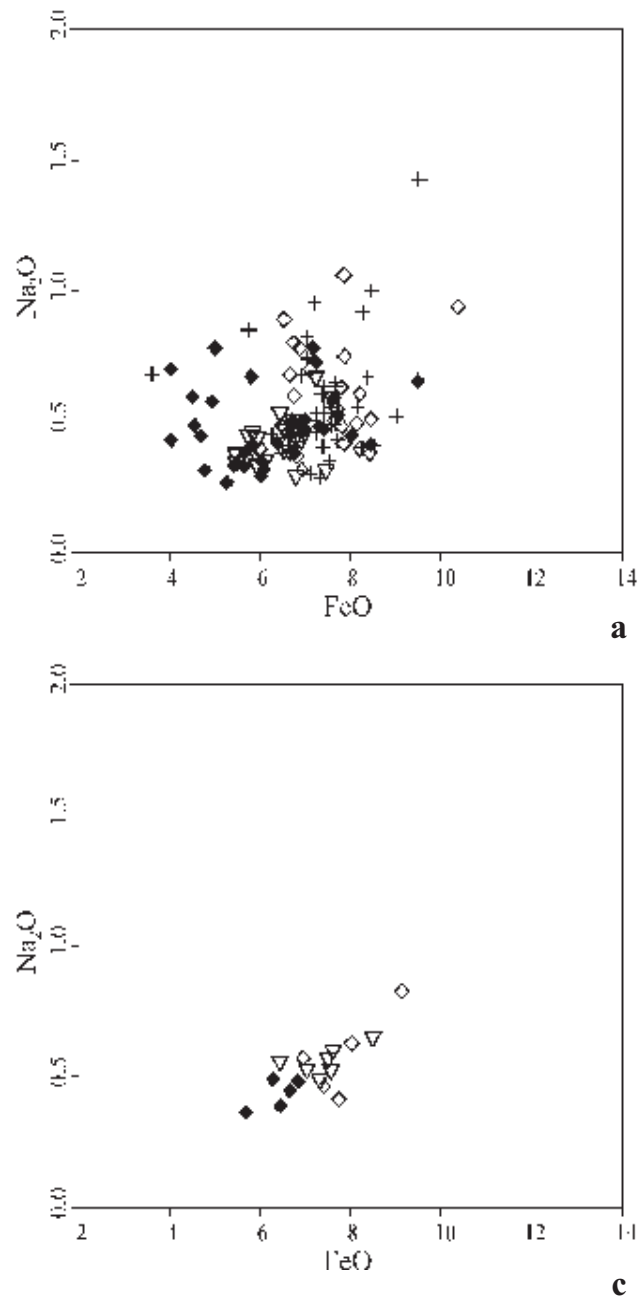
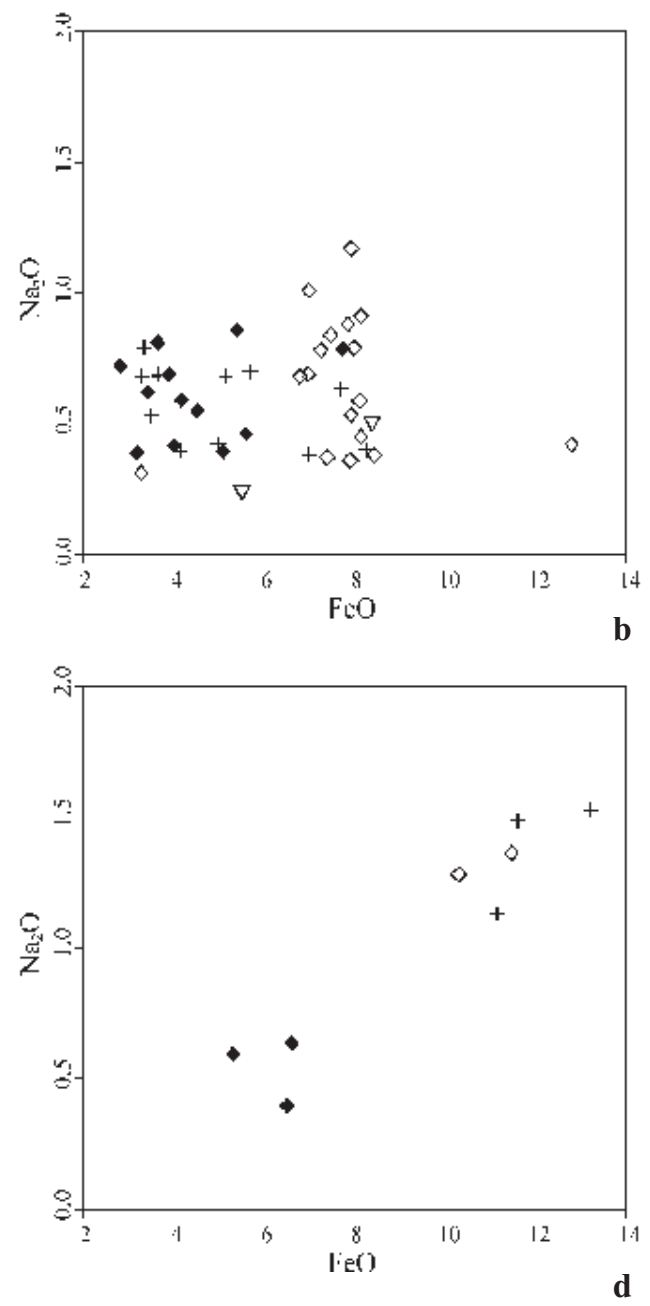

- core

$\nabla$ mantle

rim

+ microcryst in martix
Fig. $12 \mathrm{FeO} / \mathrm{Na}_{2} \mathrm{O}$ diagram symbols correspond to previous figures. a - compositional ranges of clinopyroxenes from basaltic rocks, essexite KA43 and tephriphonolite DH796; b - compositions of clinopyroxenes from basaltic rocks; c-compositions of clinopyroxenes from essexite KA43; d-compositions of clinopyroxenes from tephriphonolite DH796. 
tephriphonolitic melt. Full name of pyroxenes in tephriphonolite (rims and microcrysts) is: sodian aluminian diopside.

Similar feature of green pyroxene mantle enclosing brownish core was described from Euganean Hills in northern Italy by DePieri - Molin (1980). DePieri and Molin observed slight decrease of titanium from the brown core to the green rim (comparable to trend observed in this study), but the described trends of other elements are incomparable (e.g. Mg slightly increases toward the rim). Such strong compositional shifts observed in studied clinopyroxenes is unlikely to be produced only by changes in pressure (as supposed DePieri - Molin 1980 for weak compositional shifts in trachytic clinopyroxenes), more probable is dependence on the parental magma evolution. Moreover, green clinopyroxene rims from the DHVC tephriphonolite show the same compositions as groundmass microcrysts from phonolites and trachytes from Tenerife (Scott 1976). Trachyandesitic clinopyroxenes from the same locality (Scott 1976) have more primitive composition (lower $\mathrm{Fe}^{2+} / \mathrm{Mg}$, etc.).

\section{Conclusions}

The mineralogical investigation of clinopyroxenes in volcanic rocks of the DHVC brought several important results:

1) The studied clinopyroxenes generally fit the field of diopside in Wo-En-Fs diagram (Morimoto 1988). Traditional term "augite" should not be used according to the present mineral chemistry information. Clinopyroxenes from individual petrographic groups are classified as follows:

a) cores of clinopyroxenes from basaltoids should be classified as aluminian diopsides, whereas rims and microcrysts with higher Ti correspond to titanian aluminian (subsilicic) diopsides.

b) cores of clinopyroxenes from picrobasalts have composition of chromian aluminian diopsides, whereas their rims of aluminian diopside composition are similar to pyroxenes from basaltoids.

c) compositional shift in clinopyroxenes from essexite is similar to basaltoids with aluminian diopsides in cores and titanian aluminian subsilicic diopsides in rims.

d) composition of clinopyroxene cores from the tephriphonolite is similar to cores from basaltoids of aluminian diopside composition, whereas rims of clinopyroxenes differ in composition and should be classified as sodian aluminian diopsides.

2) Trends in clinopyroxene zoning:

a) clinopyroxenes from basaltoids and essexite show similar trend in decrease of $\mathrm{Si}$ and $\mathrm{Mg}$ and increase in $\mathrm{Fe}, \mathrm{Ti}, \mathrm{Al}$ and $\mathrm{Na}$ towards the rim. Clinopyroxenes from picrobasalts show similar trend with higher initial $\mathrm{Si}$ and $\mathrm{Mg}$ content. Clinopyroxene rims from picrobasalts compositionally correspond to cores of clinopyroxenes from basaltoids. Such compositional shift correspond to differentiation of basaltic melt.

b) cores of clinopyroxene from tephriphonolite have the same composition as cores from basaltoids, but their rims differ significantly in strong decrease in $\mathrm{Mg}$ and increase in $\mathrm{Fe}$ and $\mathrm{Na}$. Such distinctive compositional shift could be explained by a sudden change in the parental magma composition (magma mixing?).

Acknowledgement. The presented problematic has been studied within the framework of the geological mapping of the Czech Republic at a scale of 1:25 000, conducted by the Czech Geological Survey (especially map sheets 11-221 and 11-223, covering the Doupovské hory Mts.). F. Holub, F. Fediuk and V. Janoušek are gratefully acknowledged for constructive comments and S. Vrána for correcting English. My thanks also go to reviewers J. Ulrych and V. Erban.

Submitted March 21, 2006

\section{References}

Cajz, V. - Vokurka, K. - Balogh, K. - Lang, M. - Ulrych, J. (1999): The České stř̌edohoří Mts.: Volcanostratigraphy and Geochemistry. Geolines, 9: 21-28.

Cameron, M. - Papike, J. J. (1981): Structural and chemical variations in pyroxenes. - Amer. Mineralogist, 66: 1-50.

- (1982): Crystal Chemistry of silicate pyroxenes. - in: Prewitt, C. T. (ed.): Reviews in mineralogy. Vol. 7.: Pyroxenes. - Mineral. Soc. Am., Washington D. C., Chapter 2: 5-92.

Christensen, N. I. - Medaris, L. G. - Wang, H. F. - Jelinek, E. (2001): Depth variation of seismic anisotropy and petrology in central European lithosphere: A tectonothermal synthesis from spinel lherzolite xenoliths. - J. Geoph. Res. - Solid Earth, 106, B1: 645-664.

Deer, W. A. - Howie, R. A. - Zussman, J. (1997): Rock-Forming Minerals. Vol. 2A: Single-Chain Silicates, Second edition. Longman, London, $668 \mathrm{pp}$.

DePieri, R. - Molin, G. M. (1980): Trachyte pyroxenes in the Euganean Hills (Northern Italy). - N. Jb. Min. Abh., 138(1): 64-80.

Dèzes, P. -Schmid, S. M. -Ziegler, P. A. (2004): Evolution of the European Cenozoic Rift System: interaction of the Alpine and Pyrenean orogens with their foreland lithosphere. - Tectonophysics, 389: 1-33.

Dobosi, G. (1987): Chemistry of clinopyroxenes from the Lower Cretaceous alkaline volcanic rocks of the Mecsek Mountains, South Hungary. - N. Jb. Min. Abh., 156(3): 281-301.

- (1989): Clinopyroxene zoning patterns in the young alkali basalts of Hungary and their petrogenetic significance. - Contrib. Mineral. Petrol., 101(1): 112-121.

Dobosi, G. - Downes, H. - Embey-Isztin, A. - Jenner, G. A. (2003): Origin of megacrysts and pyroxenite xenoliths from the Pliocene alkali basalts of the Pannonian Basin (Hungary). - N. Jb. Miner. Abh., 178(3): 217-237.

Gupta, A. K. - Onuma, K. - Yagi, K. - Lidiak, E. G. (1973): Effect of silica concentration on the diopsidic pyroxenes in the system diopside-CaTiAl $\mathrm{O}_{6}-\mathrm{SiO}_{2}$. - Contr. Mineral. Petrol., 41: 333-344.

Hradecký, P. (1997): The Doupov Mountains. - In: Vrána, S. - Štědrá, V. (eds.): Geological model of Western Bohemia related to the KTB borehole in Germany. - J. Geol. Sci., 47: 125-127.

Hradecký, P. - Adamová, M. - Bohdálek, P. - Elznic, A. - Godány, J. Hrazdira, P. - Kotková, J. - Manová, M. - Mlčoch, B. - Nekovařik, Č. - Šalanský, K. - Šebesta, J. (2000): Explanations to geologic map of the Czech Republic 1:25 000, sheet 11-222 Kadaň (in Czech). - Unpublished report, Czech Geological Survey, Prague. 
Hradecký, P. - Adamová, M. - Godány, J. - Holub, F. V. - Hrazdira, P. Kotková, J. - Lochmann, Z. - Manová, M. - Mlčoch, B. - Nekovař́k, Č. - Rapprich, V. - Stárková, M. - Šalanský, K. - Šebesta, J. (2002): Explanations to geologic map of the Czech Republic 1:25 000, sheet 11-221 Stráž nad Ohří (in Czech). - Unpublished report, Czech Geological Survey, Prague.

Hradecký, P. - Adamová, M. - Godány, J. - Holub, F. V. - Hrazdira, P. Krupička, J. - Mlčoch, B. - Rapprich, V. - Šebesta, J. - Štědrá, V. Skácelová, D. - Skácelová, Z. (2005): Explanations to geologic map of the Czech Republic 1:25 000, sheet 11-223 Kyselka (in Czech). Unpublished report, Czech Geological Survey, Prague.

Huckenholz, H. G. (1966): Der petrogenetische Werdegang der Klinopyroxene in den tertiären Vulkaniten der Hocheifel; III, Die Klinopyroxene der Pikritbasalte (Ankaramite). - Contrib. Mineral. Petrol., 12(1): 73-95.

- (1973): The Origin of Fassaitic Augite in the Alkali Basalt Suite of the Hocheifel Area, Western Germany. - Contrib. Mineral. Petrol., 40: $315-326$.

Huckenholz, H. G. - Schairer, J. F. - Yoder, H. S. Jr. (1969): Synthesis and stability of ferri-diopside. - Mineral. Soc. Am. Spec. Paper, 2: 163-177.

Hueber, J. S. - Turnock, A. C. (1980): The melting relations at 1 bar of pyroxenes composed largely of $\mathrm{Ca}-, \mathrm{Mg}-$, and Fe-bearing components. - Amer. Mineralogist, 65: 225-271.

Janoušek, V. - Farrow, C. M. - Erban, V. (2006): Interpretation of wholerock geochemical data in igneous geochemistry: Introducing Geochemical Data Toolkit (GCDkit). - J. Petrol., 47(6): 1255-1259.

Kopecký, L. (1987-1988): Mladý vulkanizmus Českého masívu. (Young volcanism of the Bohemian massif - in Czech). - Geol. Hydrometal. Uran., 11, 3: 30-67; 11, 4: 3-44; 12, 1: 3-40; 12, 2: 3-56; 12, 3: 340; $12,4: 3-40$.

Le Bas, M. J. - Le Maitre, R. W. - Streckeisen, A. - Zanettin, B. (1986): A chemical classification of volcanic rocks based on the total alkalisilica diagram. - J. Petrology, 27: 745-750.

Liotard, J. M. - Briot, D. - Boivin, P. (1988): Petrological and geochemical relationships between pyroxene megacrysts and associated alkali-basalts from Massif Central (France). - Contrib. Mineral. Petrol., 98: 81-90.

Martin, R. F. (1998): The nomenclature of minerals: A compilation of IMA reports. Ottawa, 149.

Mikuláš, R. - Fejfar, O. - Ulrych, J. - Žigová, A. - Kadlecová, E. - Cajz, V. (2003): A Study of the Dětaň Locality (Oligocene, Doupovské hory Mts. Volcanic Complex, Czech Republic): Collection of field data and starting points for interpretation. - Geolines, 15: 91-97.

Morimoto, N. (1988): Nomenclature of pyroxenes. - Mineral. Mag., 52: $535-550$.

Nazzareni, S. - Busà, T. - Cristofolini, R. (2003): Magmatic crystallisation of $\mathrm{Cr}-\mathrm{Al}$ diospide and $\mathrm{Al}-\mathrm{Fe}^{3+}$ diopside from the ancient alkaline basalts (Mt. Etna, Sicily). - Eur. J. Mineral., 15: 81-93.

Ponfikl, J. E. (1822): Vollständiger Umriss einer statistischen Topographie des Königreiches Böhmen. I. Abtheilung. Böhmen überhaupt.

Prewitt, C. T. (ed.) (1982): Reviews in mineralogy. Vol. 7.: Pyroxenes. Mineral. Soc. Am., Washington D.C., 525 pp.

$R$ Development Core Team (2005): R: A language and environment for statistical computing. - R Foundation for Statistical Computing, Vienna, Austria. URL http://www.R-project.org
Rapprich, V. (2003a): Petrology and geochemistry of volcanic rocks in the northern part of the Doupovské hory Mts. (in Czech). - Unpublished diploma thesis. Faculty of Science, Charles University, Prague.

- (2003b): Succession of lava flows of Úhošt' hill in relation to the history of magma reservoir. - Geolines, 16: 88-89.

Scott, P. W. (1976): Crystallization trends of pyroxenes from the alkaline volcanic rocks of Tenerife, Canary Islands. - Mineral. Mag., 40: 804-816.

Shrbený, O. (1982): Chemistry of alkaline volcanic rocks of the Doupovské hory Mts., Bohemia. - Čas. Mineral. Geol., 27 (2): 139-158.

Simonetti, A. - Shore, M. - Bell, K. (1996): Diopside phenocrysts from nephelinite lavas, Napak volcano, eastern Uganda: evidence for magma mixing. - Canad. Mineralogist, 34(2): 411-421.

Tracy, R. J. - Robinson, P. (1977): Zoned titanian augite in alkali olivine basalt from Tahiti and the nature of titanium substitutions in augite. Amer. Mineralogist, 62: 634-645.

Ulrych, J. (1983): Chemistry of sector-zoned clinopyroxenes of monchiquite and rongstockite from the České středohoří Mts. (in Czech). - Acta Univ. Carol., Geol., Rost vol. (1-2): 117-131.

- (1986): Clinopyroxenes in the Cenozoic volcanics of the České středohoří Mts.: A review. - Acta Univ. Carol., Geol., 4: 367-376.

- (1998): Geochemistry of subvolcanic alkaline rock series of the Roztoky Intrusive Centre, České středohoří Mts., Bohemia. - Erlanger Beitr. Petr. Min., 8: 1-42.

Ulrych, J. - Cajz, V. - Balogh, K. - Erban, V. (2001): Geochemistry of the stratified volcanosedimentary complex in the central part of the České středohoři Mts., North Bohemia. - Krystalinikum, 27: 27-49.

Ulrych, J. - Pivec, E. - Langrová, A. - Jelinek, E. - Árva-Sós, E. Höhndorf, A. - Bendl, J. - Řanda, Z. (1998): Geochemically anomalous olivine-poor nephelinite of Ríp Hill, Czech Republic. - J. Czech Geol. Soc., 43(4): 299-311.

Ulrych, J. - Pivec, E. - Povondra, P. - Rutšek, J. (1991): Rock-forming minerals of polzenite and cognate melilitic rocks from northern Bohemia, Czechoslovakia. - Acta Univ. Carol., Geol., 1-2: 39-70.

Ulrych, J. - Pivec, E. - Rutšek, J. - Povondra, P. (1990): Olivinesmonticellites and clinopyroxenes in melilitic rocks, Ploučnice River region, Czechoslovakia. - Acta Univ. Carol., Geol., 2: 141-164.

Vieten, K. - Hamm, H. M. (1978): Additional notes 'On the calculation of the crystal chemical formula of clinopyroxenes and their contents of $\mathrm{Fe}^{3+}$ from microprobe analyses'. - Neu. Jb. Mineral., Mh., 71-83.

Wass, S. Y. (1973): The origin and petrogentic significance of hour-glass zoning in titaniferous clinopyroxenes. - Mineral. Mag., 39: 133-144.

- (1979): Multiple origin of clinopyroxenes in alkali basalts rocks. Lithos, 12(2): 115-132.

Wiesbaur, J. B. (1901): Theralith im Duppauer Gebirge. - Lotos, 21: 62-71. Yagi, K. - Onuma, K. (1967): The join $\mathrm{CaMgSi}_{2} \mathrm{O}_{6}-\mathrm{CaTiAl}_{2} \mathrm{O}_{6}$ and its bearing on titanaugites. - J. Fac. Sci. Hokkaido Univ. Ser., 13: 117-138.

Zartner, W. R. (1938): Geologie des Duppauer Gebirges. I. Nördliche hälfte. - Abh. Dtsch. Gesell. Wiss. und Künste in Prag. 132 pp.

Web references: Complete dataset of clinopyroxene analyses used for presented paper: http://www.geologickaspolecnost.cz/jcgs/content/ JCGS2005_3-4_rapprich/

\section{Variace chemického složení klinopyroxenů v bazaltických, essexitových a tefrifonolitových horninách vulkanického komplexu Doupovských hor, severozápadní Čechy}

Studovány byly variace v chemickém složení klinopyroxenů vulkanických hornin (lávy a mělce intruzívní tělesa) Doupovských hor. Vysoké obsahy Ca (většinou nad $90 \% \mathrm{M} 2$ pozice) a Mg řadí studované pyroxeny $\mathrm{k}$ diopsidům. S ohledem na obsahy $\mathrm{Al}$ a Ti, je ve většině př́ípadů doporučeno použití názvu titaničito hlinitý diopsid. Původní a tradičně uživané označení augit již není možné, s ohledem na analytická data a klasifikaci pyroxenů, používat.

Během krystalizace bazaltických hornin se složení pyroxenů posouvalo k železem bohatšímu diopsidu v okrajích vyrostlic a v mikrokrystalech základní hmoty. Obsahy Al, Ti a Fe vzrůstají směrem od jádra k okrajům vyrostlic, zatímco obsahy Si a Mg klesají. Stejné posuny v chemizmu byly dokumentovány v klinopyroxenech studované essexitové horniny. V zonalitě klinopyoxenů tefrifonolitu je zaznamenána změna chemismu krystalizujíćího magmatu. Jádra klinopyroxenových vyrostlic mají složení podobné klinopyroxenům z bazaltických hornin, zatímco okraje tvořené sodno hlinitým diopsidem se vyrazně odlišují vyššími poměry $\mathrm{Fe} / \mathrm{Mg}$ a Na/Ca a nízkým obsahem Ti. 